\title{
Kadim Bilgelik Miti ve Tüketim Toplumu İkonu Olarak Geyik Sembolizmi
}

\author{
Oya Ayan (Doktora Öğrencisi) \\ İstanbul Ticaret Üniversitesi \\ oya.ayan@gmail.com \\ Başvuru Tarihi: 01.09.2020 \\ Yayına Kabul Tarihi: 12.01.2021 \\ Yayınlanma Tarihi: 29.01.2021 \\ https://doi.org/10.17680/erciyesiletisim.789164 \\ Öz
}

$\mathrm{Bu}$ makalede, geyik mitinin geçmişten günümüze imgeleşerek kült hâline gelişine odaklanılmaktadır. Geyik mitine hem Doğu hem de Batı medeniyetlerinin yazılı kaynaklarında geniş bir şekilde yer verildiği görülmektedir. Bunun nedeni, efsanelerde, menkıbelerde, destanlarda, ayinlerde geçen geyik mitinin insanlar için temsili özellikleri olmalıdır. Söz konusu çalışmada geniş bir tarama yapılarak biri Doğu biri de Batı uygarlığından geyik sembolü içeren temsili iki görsel seçilmiştir. Bu görsellerin okunmasında kuram olarak Göstergebilim yöntemine başvurulmuştur. Böylelikle makalede, geyik figürü üzerine yoğunlaşılarak kadim bilgelikte ve sosyal antropolojide söz konusu geyik mithosunun nasıl dönüştürüldüğü evreleriyle birlikte ortaya konmaya çalışılmıştır. Bu çerçevede dinsel, hatta metafiziksel bir mitin nasıl dünyevileştirildiği, büyüsünün ve sihrinin muhafaza edilerek liberalizmin potasında nasıl kendisine özgü bir mistik özellik kazandırıldığı vurgulanmaktadır. Son bölümde ise literatür araştırmaları doğrultusunda dinsel bir mit olarak Anadolu efsanelerinin özüne sinen Hacı Bektaş-i Veli'nin bulunduğu bir resim ile kapitalizmin miti hâline dönüștürülen Noel Baba'nın bulunduğu bir poster üzerinde karşılaștırmalı görsel okuma yapılmaktadır. Göstergebilim yaklaşımıla geyik sembolünün kadim bilgelik mitinden tüketim toplumu ikonu hâline dönüşümü kaydedilmektedir.

Anahtar Kelimeler: İletişim, Geyik Miti, Hacı Bektaş-i Veli, Noel Baba, Göstergebilim. 


\title{
Deer Symbolism as Ancient Wisdom Myth and Icon of Consumption Society
}

\author{
Oya Ayan (Ph.D. Student) \\ İstanbul Commerce University \\ oya.ayan@gmail.com \\ Date Received: 01.09.2020 \\ Date Accepted: 12.01.2021 \\ Date Published: 29.01.2021 \\ https://doi.org/10.17680/erciyesiletisim.789164
}

\begin{abstract}
This article focuses on how the deer myth is perceived in legends, rites, and rituals. In this study, two representative images, one from the East and the other from the Western civilization, containing deer symbols, were selected by making a wide investigation. To read these visuals, the semiotics method was used as a theory. Thus, the article focused on the deer figure and tried to reveal how the deer mythos in question was transformed into ancient wisdom and social anthropology, together with its stages. In that respect, it is also emphasized that how a religious and even metaphysical myth is secularized, but its magic and spell have been maintained, and that liberalism has been brought to its own spirituality. In the last part of the article, a comparative visual reading is made through a picture with Haji Bektash Veli, who is loyal to his essence as a religious myth in line with the literature researches, and a poster with Santa Claus, who has been turned into a myth of capitalism. With the semiotics approach, the transformation of the deer symbol from the ancient wisdom myth to the consumer society icon is recorded.
\end{abstract}

Keywords: Communication, Deer Myth, Haji Bektash Veli, Santa Claus, Semiotics. 
Giriş

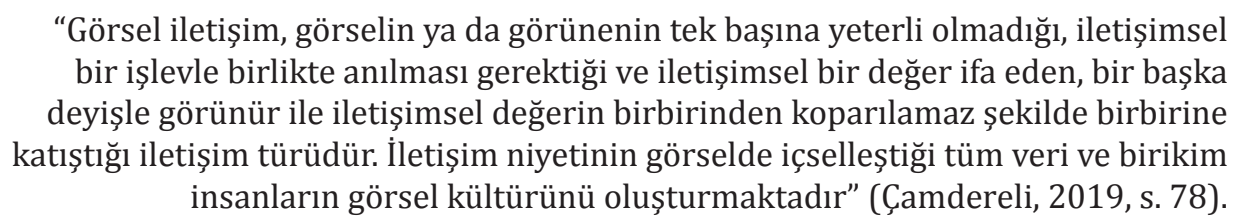

Bu tanımı bize sunan Çamdereli aynı yerde yapmış olduğu açıklamada kimi zaman bir resmin, bir heykelin görsel koda haiz bir kültür verisi iken kimi zaman da bir reklam afişinin görsel kültürün dışavurum araçları olarak besleyici, destekleyici bir işlev üstlendiğini ifade etmektedir. Reklam konusundaki çalışmalarını da bildiğimiz Çamdereli'ye göre; "Reklamın doğasına en uygun dil kuşkusuz simgesel dildir. Reklam, söylemini bu simgesel dil ile yansıtır; söylemini bu dille taşır, bu dilde yaşatır ve bu dille aktarır. $\mathrm{Bu}$ dille imgelememizi işgal eder, gelecek umutlarımızın, beklentilerimizin sınırlarını çizer; düşlerimizi kullanır, ayartır" (2004, s. 57).

Günümüz tüketim toplumunda bu sembolik dil etkili bir şekilde kullanılarak bir yandan insanların kutsal kabul ettikleri bazı simgelerin mistik gücünden faydalanılıp tüketim teşvik edilirken diğer yandan da kutsal olan simge insanların algısında profanlaştırılmaktadır. İlginç olan nokta, içinde bulunduğumuz, insanların birbirilerini ve kendilerini dahi tükettikleri bu tüketim çağında sembollerin anlamının kadim uygarlıktaki gücünden faydalanmak için geçmişe kadar gidilmesidir.

Dünya mitolojisi çeşitli hayvanların, ekoloji ile iç içe yaşayan insanların hayatındaki kutsal tezahürlerini kaydetmektedir. Türk tarihi uzmanı Fransız profesör Jean-Paul Roux, Orta Asya kültürel coğrafyası üzerine yapmış olduğu çalışmalarda yaşamın en mükemmel ve güçlü ana kaynağını hayvanların, bitkilerin oluşturduğunu tespit etmiştir. Buradan hareketle tarihsel döngü içerisinde her zaman toplulukların ilgi alanlarının en ön sırasında yer aldığını vurgulamıştır. Araştırmacı bitki ve hayvanların simge, örnek ya da eyleyen olarak anıldığını, kısacası yaşamın temel tezahürü hatta varoluşun ifadesi olduklarını dile getirmektedir (Roux, 2005, s. 13).

Mitlerde ve efsanelerde rol oynayan, kurban hayvanı olarak sunulan ya da büyü törenlerinde kullanılan "kutsal" hayvanlarla ilgili uzun bir liste bulunmaktadır (Roux, 2005, s. 16). Makalenin inceleme konusunu bu listeden seçilen geyikgiller (Türk Dil Kurumu Sözlükleri, t.y.) oluşturmakta ve onların eyleyen olarak yer aldıkları mitolojilerdeki sembolik göndergelerine odaklanılmaktadır.

Geyik kültü kadim kültürde karşımıza sıklıkla çıkan sembollerden bir tanesidir. $\mathrm{Bu}$ makalede mistik bir sembol olan geyiğin zaman içerisinde yaşadığı metamorfoz ele alınmaktadır. Geyik sembolünün kutsanması, temsil ettikleri, Orta Asya'da şamanlardan gelip Anadolu erenlerinin menkıbelerine konu olması ve Noel Baba'nın tüketim toplumu geyiğine dönüşümü, literatür araştırmaları ve seçilen görsellerin okunması ile ortaya konulmaya çalışılmıştır. Bu amaçla, öncelikle bir literatür taraması yapılmış ve görüntü okumalarında çokça tercih edilen Göstergebilim yönteminden yararlanılmıştır. Seçilen görseller üzerinde Göstergebilimsel okuma işlemi gerçekleştirilirken, geyik figürünün geçmişten günümüze nasıl dönüşüm geçirdiği de aktarılmaktadır. Çözümlemesi üzerinde çalışılan görseller, okuma sürecinde, kültürel antropolojik bağlamda ele alınmaktadır. Konunun mit ve mitoloji kayıtları doğrultusunda değerlendirerek işlenmesi öngörülmektedir. 


\section{Mit ve Mitoloji Kavramları}

Mit olgusu kadim bilgelikte olayları ve süreçleri anlamlandırmada işlevsel bir özelliğe sahip iken pozitivist bilimselciğin yükselişi bizi sembolleri okumada çok önemli bir boyuttan mahrum bırakmıştır. Oysaki Özçetin'in (2019) ifade ettiği gibi "Kapitalist modernlik ve aydınlanma bireyin ve bir bütün olarak insanlığın kurtuluşunu vaat etmiş ve miti kendine en büyük düşman olarak belirlemiştir. Oysa Horkheimer ve Adorno'ya göre mit / söylence aydınlanmanın ta kendisidir ve aydınlanma mite / söylenceye geri döner" (s. 170). Bu düşünceden hareketle inceleme kapsamına aldığımız geyik sembolü ile ilgili artalan bilgisine geçmeden önce konu ile ilgili mit ve mitoloji olgularına göz atmakta yarar bulunmaktadır.

\subsection{Mit Olgusu}

Mit konusunda çok farklı yaklaşımlar bulunmaktadır. Sosyologlardan antropologlara farklı disiplinlerden bilim adamlarının mit olgusu üzerinde çalıştığı görülmektedir. Kültür antropolojisinin öncüsü olan Bronislaw Malinowski, psikoloji ile mitoloji ilişkisini inceleyen, karşılaștırmalı mitoloji sahasının önde gelen kuramcılarından Joseph Campbell, mitosların kolektif bilinçdışının izleri olduğunu belirten Jung ve daha birçok bilim adamı bu alanda önemli eserlere imza atmışlardır. Bu çalışmada ise dinler tarihçisi ve filozof olan ünlü akademisyen Mircea Eliade'nin tanımı çerçevesinde mit ve mitoloji olgusu ele alınacaktır.

Mit kelimesi günümüzde "fabl", "kurmaca" ya da "hayal" anlamında kullanılır. Başta Eliade olmak üzere etnologlar, toplumbilimciler ve din tarihçileri arasında yaygın olarak; "kutsal gelenek, en eski vahiy, örnek gösterici model" şeklinde tanımlanır (Eliade, 2018, s. 11).

Arkaik toplumlarda mit hakkındaki söylenenlere bakıldığında; mit doğaüstü varlıkların eylemlerinin öyküsünü oluşturmaktadır. Bu öykünün kesinlikle gerçek ve kutsal olarak kabul edildiği görülmektedir. Mit özünde yaratılışla ilgilidir. Bir şeyin yaşama geçişine ya da bir davranışın, bir kurumun, bir çalışma şeklinin yaratılışına tercüman olur. Dolayısıyla mitler insana özgü her anlamlı eylemin örnek tiplerini oluştururlar. İnsan miti bilmekle nesnelerin kökenini kavrar, onlara egemen olmayı ve onları istediği gibi yönlendirip kullanmayı başarabilir. Mitin tören havasında anlatılması ya da kanıtını oluşturduğu ritüelin gerçekleşmesiyle yaşanan bir bilgi söz konusudur. İnsan, miti yeniden anımsatılan ve yeniden gerçekleşme aşamasına getirilen olayların kutsal, coşku verici gücünün etkisine girmek anlamında yaşar (Eliade, 2018, s. 32-33). Yaşayan mit ile kastedilen, mitin insan davranışı için bir model oluşturması ve bu yolla yaşama anlam ve değer katmasıdır (Eliade, 2018, s. 12).

Mitin insan davranışlarında model teşkil etmesinin, insanların yaşamında ve bilinçaltında oynadığı rolün keşfi, iletişim uzmanlarının çeşitli iletişim çalışmalarında mitsel yapıları kullanmasını sağlamıştır. Yapılan son araştırmalar, kitle iletişim araçları yoluyla topluluklara zorla benimsetilen imgeler ve davranışların mitsel yapılarını aydınlatmıştır. Mitler kullanılarak toplumun büyük bir bölümünün idealleri somut bir biçimde canlandırılmaktadır. Bu konuda Superman miti örnek verilebilir. Superman Tanrı'nın sevgisini kaybettiğini ve gücünün sınırlı olduğunu bilen, günün birinde önemli bir kahraman olarak ortaya çıkacağını hayal eden modern insanın gizli özlemlerini karşlamaktadır (Eliade, 2018, s. 242-243). 


\subsection{Mitoloji Olgusu}

Türk dünyasında mit ve mitolojinin karşılığı olarak Arapça "ustûre" ve bu kelimenin çoğulu olan "esatir" terimleri kullanılmıştır. Zaman zaman Farsça "efsane" ve "fesâne" kelimeleri de mit ve mitoloji karşılığı olarak verilmiştir (Un, 2011, s. 1). Yunanca'da

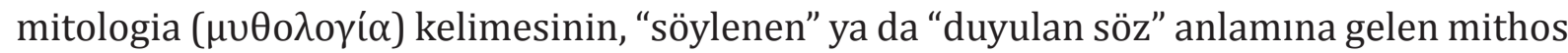

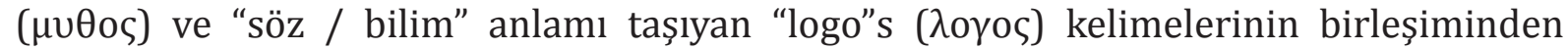
oluştuğu görülmektedir. Mitoloji kelimesi, Eski Yunan'da geçmişte söylenenlerin tekrar edilmesi anlamına gelmektedir. Batı dillerinde ise "efsane" olarak kullanılmıştır. Günümüzde mitolojinin, belirli bir din veya kültürdeki mitlerin bütününü adlandırmak için kullanıldığı (örneğin: Yunan mitolojisi, Türk mitolojisi, Hint mitolojisi) görülmektedir (Akcan, 2019, s. 51).

Efsaneler Tanrıları, kahramanları ve doğaüstü varlıkları konu alan metinlerdir. Genellikle sözel olarak ozanlar, baksılar, manasçılar, rahipler tarafından yayılarak canlı tutulurlar. Topluluğun dini veya ruhani yaşantıları ile ilişkili olan mitler, toplumdaki ruhani konumlarını yitirdikleri zaman, mitolojik özelliklerini de yitirirler ve âdeta folklorik söylenceler veya peri masalları hâline dönüşürler (Yayla, t.y., s. 1).

Mitolojinin büyük kısmının dinde önemli ve öncelikli bir yeri bulunmaktadır. Mitin, günlük kullanımdakinin tersine, hikâyenin nesnel anlamda yanlıș veya doğru olduğunu tanımlamadığı kaydedilmektedir. Nesnel veya materyalist nosyonlardan ilgisiz bir șekilde, doğru kavramının ruhsal, psikolojik ve/veya sembolik yönlerine de gönderme yaptığı vurgulanmaktadır (Yayla, t.y., s. 2). Bu makalede göstergebilimsel çözümlemesi yapılacak olan görsellerin metafiziksel arka planını okuyabilme için mit ve mitolojinin özel bir işlevi olduğu görülecektir.

\section{Geyik Sembolü ve Kültürel Yansımaları}

Biri mit, biri ikon olarak çözümleme kapsamına aldığımız iki kültürel/dinsel karakteri anlamayı kolaylaştıracak bilgisel bir arka plan oluşturmak gerekir. Bunu yapmak için geyik sembolünü çeşitli yönleriyle irdelerken mitsel göndergelerini de betimlemek uygun olacaktır. İnceleme nesnesi olarak belirlediğimiz dinsel/kültürel karakter için Doğu'da Geyik Sembolü ve Batı'da Geyik Sembolü olarak başlıklar oluşturulmuştur. Başlıklardan birincisi Hacı Bektaş-i Veli okuması, ikincisi Noel Baba okuması ile ilgili arka plan oluşturacaktır.

\subsection{Doğu'da Geyik Sembolü}

Tarihsel perspektif ışığında Türk kültürel coğrafyasında geyik sembolizminin şamanik kökenlerine öncelikle değinilecektir. Bunu takiben, Orta Asya'dan başlayarak Anadolu'ya kadar geyik sembolünün destanlara konu edilişi üzerinde kısaca durulacaktır. $\mathrm{Bu}$ bağlamda İslami menkıbelerde ve tasavvufi literatürde geyikgillerin yer aldığı göndergeler ele alınarak irdelenecektir. Bu konudaki malzemenin yoğunluğu, bu makalenin boyutları içerisinde seçici olmayı gerektirmiştir.

\subsubsection{Orta Asya Şaman Türklerinde Geyik Sembolü}

"Şamanizm, şaman ya da kam adı verilen din adamları aracılığıyla uygulanmaya çalıșılan bir inanışlar bütünüdür. Stricto sensu (dar anlamda) şamanizm tipik olarak Sibirya ve Orta Asya'ya özgü bir dinsel olgudur. Terimi bile Rusça aracılığıyla, Tunguzca "şaman" sözcüğünden gelir" (Eliade, Şamanizm, 2006, s. 22). Şamanizm, Orta Asya'da görülen en önemli metafiziksel olgularından biridir. Ancak uzmanlara göre hiçbir şekilde din değildir. Şamanlık inancı üzerinde derinlemesine araştırmalar yapmış olan Mircea 
Eliade, bütün Orta ve Kuzey Asya topluluklarında, sihirsel/dinsel hayatın daha çok şaman etrafında döndügünü ifade eder. Eliade'ye (2006) göre sihirsel/dinsel hayat şamanlıktan ibaret değildir. Her sihirbazın şaman sayılmadığını vurgulayan Eliade şamanı şöyle tanımlamıştır:

\begin{abstract}
"Bu elbette onun kutsal olanla elleşen tek kişi olduğu ve dinsel etkinliğin bütünüyle onun tekelinde bulunduğu anlamına gelmez. Birçok kabilede şamanın yanı sıra kurban sunucu bir rahip de vardır; ayrıca her aile reisi evdeki dinsel yașamın da bașıdır. Gene de șaman en önemli kişi özelliğini korur, çünkü esrime (vecd, extase) deneyiminin en yetkin dinsel deneyim sayıldığı bütün bu bölgelerde, esrime'nin baş ustası yalnızca şamandır. Bu karmaşık olayın ilk tanımı - belki de en azından yanılma payı taşımayan tanımı - şöyle olmalıdır: şamanlık = esrime tekniği" (2006, s. 22-23).
\end{abstract}

Öte yandan şamanlıkta şifagüderlik de temel unsurlardan biri olarak karşımıza çıkmaktadır. Şamanın sağaltıcı sahadaki en belirgin gücü, onun kendi içsel enerjisini kullanabilen bir esrime üstadı olmasıdır. Eliade şamanlığı "extase" (yüksek haz heyecanı ile insanın kendinden geçmesi) tekniği olarak açıklar. Ancak, her extase hâli şamanik olmamaktır. Şaman her şeyden ötesinde bir transe yani esrime, vecd ustasıdır. Esrime ustası olan şamanın ruhu bedeninden ayrılarak hastaların ruhlarına şifa verir. Bu doğaüstü yetenekleriyle insanlarla Tanrılar arasında iletişimde aracılık yaparlar (Yayla, t.y., s. 4-5). Öyle ki Eliade (2006), şamanı tanımlarken "Şaman aslında bir sihirbaz ve otacıdır; bütün hekimler gibi onun da hastalıkları sağalttığına; ilkel ve çağdaş bütün sihirbazlar gibi fakirsel mucizeler gösterdiğine inanılır. Ama o, bunlardan başka, ruhgüder (psychopompe)dir ve ayrıca rahip, mistik ve ozan da olabilir" diye ifade etmektedir (s. 22). V

Ne var ki, burada söz konusu olan sihirbazlardan farklı olarak şaman olmak; "ateşe egemen olma", "sihirli uçuş" gibi özel bir sihirsel uzmanlıktır. Bu nedenle şamanlık sihirbazlığı kuşatsa da her sihirbazın şaman olduğu söylenememektedir (Eliade, Şamanizm, 2006, s. 23). Şamanı ilkel toplumların öteki sihirbazlarından ve otacılarından ayırt etmek gerekirse, şaman, ruhu bedeninden ayrılarak göğe tırmanabilen ya da yer altına inebilen yani toplumun diğer bireylerinin ulaşamadığı kutsal bölgelere erişebilen özel bir esrimenin uzmanıdır. Şamanlar seçilmiş kişilerdir. Toplumun diğer üyelerinin ulaşamadığı bir kutsal alana erişebilirler. Şamanların bahsedilen mistik deneyimleri, dinsel ideolojinin katmanlaşmasını, mitolojiyi ve törenler sistemini güçlü bir şekilde etkilemektedir (Eliade, Şamanizm, 2006, s. 25-26).

Şamancıl törenlerde kullanılan davul, semboller içerinde birinci planda rol almaktadır. Simgeselliği karışık, sihirli işlevleri çoktur. Şaman adaylarının sırra-erme rüyalarından birçoğu evren ağacının ve Evrensel Hâkimin bulunduğu yere yani dünyanın merkezine yapılan mistik bir yolculuk içermektedir. Şaman, davulunun kasnağını Yüce Varlığın bu iş için düşürdügü özel bir daldan yapar. Şaman davulunu çalmakla göğe çıkarak, dünyanın merkezine yani evren ağacının yanına fırlatılmış olur. Davulun buradaki simgeselliğine bakıldığında, şamanın göğe çıkmak için kullandığı bir araç olarak çok basamaklı bir şaman ağacına benzetilebileceği söylenmektedir (Eliade, 2006, s. 199-200).

Şekil 1'de Orta Asya, Şekil 2'de ise Amerika uzamında bir şamanın davulu ile mistik çalışması görülmektedir. Bu ritüelde şaman, davulunu çalarak ruhları çağırmaktadır. Çağırdığı ruhları davuluna hapsederek esrimeli yolculuğun öz hazırlığını yerine getirmektedir. $\mathrm{Bu}$ nedenle davula şamanın atı denmektedir. Altay davulunun üzerinde bir at resmi vardır; şaman davulu çalarken atının üzerinde göğe çıktığı kabul edilir. Davulun derisi eğer bir karacadan alınmışsa davulun adı da şamanın karacası olur. Yakut 
söylenceleri, şamanın davuluyla yedi gökte nasıl dolaştığını anlatır. Karagas ve Soyot şamanları, "Yabani bir karacayla geziyorum!" diye irlarlar. Moğol kabilelerinde şaman davuluna kara geyik adı verildiği de kaydedilmektedir (Eliade, 2006, s. 204-205).

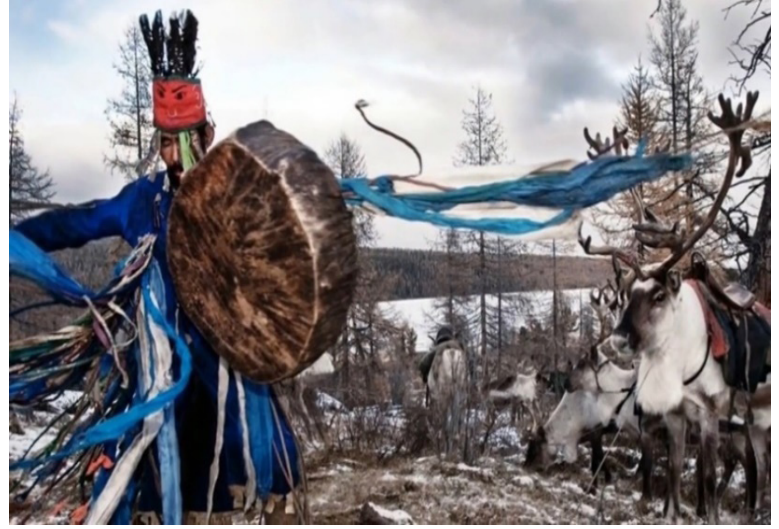

Şekil 1. Orta Asya Şaman Geleneğine İlişkin Temsili Bir Görsel (Youtube, 2016)

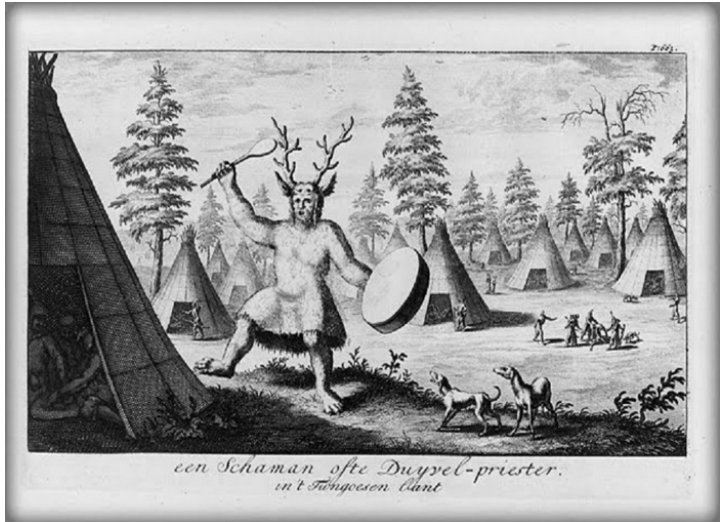

Şekil 2. Geyik Postuna Girmiș Șaman Temsili (Youtube, 2016)

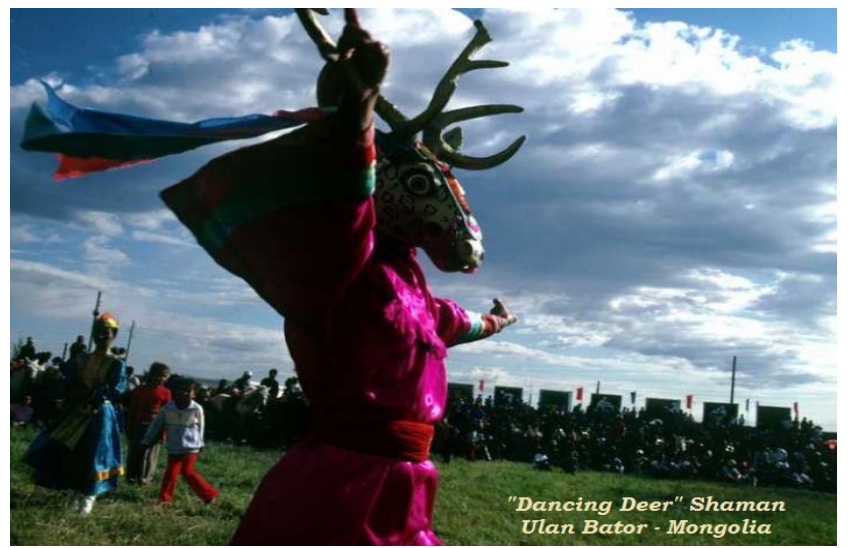

Şekil 3. "Danseden Geyik" Șaman Ulanbatur - Moğolistan (Youtube, 2016)

Öte yandan şamanlar, geyik boynuzunu şifa çalışmalarında da kullanmışlardır. Şekil değiştirme unsuru olarak; geyik şaman törenlerinde Şekil 3'te görüldüğü üzere biçimine girilen hayvan ruhlarından biridir. Erken devir insanları geyik sesi çıkarıp geyik postu giymek suretiyle kolay avlanma, başka hayvanlardan korunma veya hayvan gücüne sahip olma arzusu ile onları taklit etmektedir. Şamanların şenliklerde öldürdükleri geyiğin postuna bürünerek geyiğin ruhunu geri çağırdıkları bazı yazılı kaynaklarda yer almaktadır. Ayrıca kaynaklarda İslamiyet öncesi geyik biçimine girmenin, dini yaymak için keramet olarak kullanıldığından da bahsedilmektedir (Gök, 2019, s. 382).

\subsubsection{Türk Destanlarında Geyik Sembolü}

Geyik, Türk Destanlarında, ormanların, dağların ve sarp kayalıkların bir görünüp bir kaybolan gizemli hayvanlarından biridir. Avlanması zor bir hayvan olduğu için bir yandan ulaşılmaz sayılırken diğer yandan öldürülmesi güç olduğu için de ölümsüz sayılmıştır. İslam öncesi Türk halkları için Geyik Tanrı'nın hayvanıdır. Geyik motifi, Türk efsanelerinde geyiğin kutsallığı ve dokunulmazlığı olarak farklı şekillerde karşımıza çıkmaktadır. Geyikgiller ve geyik sembolü, dilimizde, müziğimizde, destanlarımızda, edebiyatımızda, halımızda, takımızda, kısacası sosyal yaşantımızın pek çok yerinde farklı renk ve şekillerde yer almaktadır (Aytaş, 1999, s. 161-170). 
Sevimli, çevik, naif, ince, zarif olan geyiğin özelliklerinden edebiyatta benzetme unsuru olarak faydalanılmıştır. Ürkektir; insan görünce hızla kaçar, arkasından sürüklediği kişiyi ise dermansız bırakır. Issız yerlerde yaşar. Geyik avlamak büyük bir uğursuzluk olarak görülmektedir. Avlayan iflah olmadığı gibi, avlanmış geyiğin gittiği evin de perişan olduğu söylenmektedir. Sadece avlayan avcı sıkıntı yaşamakla kalmaz, bedduası avcının soyuna dahi etki etmektedir. Mukaddes bir hayvandır. Mutlu sona erdiricidir. Sevgi perisidir. Totemdir, ruhların üzerinde dolaştığı ilahi bir varlık olarak tanımlanmaktadır. Tanrı'nın elçisidir. Sevgi perisi ve Tanrı'nın elçisi olarak da adlandırılmaktadır. (Beşkardeş, Uslu, \& Uslu, 2014, s. 18).

Geyik sembolü Dede Korkut destanında Bamsı Beyrek ve Banı Çiçek'in hikâyesinde de önemli bir rol üstlenmektedir. Geyik, doğdukları zaman beşik kertmesi yapılan ancak birbirlerinden henüz haberi olmayan Bamsı Beyrek ile Banı Çiçek'i bir araya getirmektedir (Dalkesen, 2015, s. 65). Bamsı Beyrek geyiğin peşinden giderek, nişanlısı Banı Çiçek'in otağının önüne varmaktadır. Burada doğaüstü yardımcı, haberci, yol gösterici olan geyik aslında kahramanı erginleme macerasına bașlatmaktadır. Geyik aslında bu yolculukta Bamsı Beyrek'e aşkı verecek olan bir dişi figür ile karşılaşmasına dolayısıyla ruhsal bir dönüşüm yaşayacağı bir sürecin içerisine girmesine vesile olacaktır. (Özkan, 2010, s. 86).

Geyik donuna girme motifi tasavvufi menkıbeler başta olmak üzere mistik metinlerde sıkılıkla görülmektedir. Efsanelerde eski çağlardaki av Tanrıçası Artemis'ten Türk kültüründeki ermişlere kadar geyik kılığına girdikleri anlatılmaktadır. Geyik kutsal bir hayvan sayıldığı için avı günah sayılır, uğursuzluk getireceğine inanılır. Bunun temelinde Hacı Bektaş-i Veli, Abdal Musa gibi ermişlerin geyik donuna girmesi yani geyik suretine bürünmesi de yatmaktadır. Orhan Gazi'nin çağdaşı Geyikli Baba tam bir geyik-insan olarak tanımlanır. Geyikli Baba rivayete göre Abdal Musa'ya geyik sütü ikram ederek onu da geyik türü ile akraba yapar. Türk mitolojisinde geyik, avcılardan avı saklar, av hayvanlarını korur, insanlara doğru yolu gösterir ve yurdun sınırlarını belirler. Ala geyiğin aslında don değiștirmiş insan olduğu düșüncesiyle de öldürülmesinin iyi olmayacağı kanaati yaygındır (Şahin, 2014, s. 636).

Yaşar Kemal'in Üç Anadolu Efsanesi kitabındaki "Alageyik" hikâyesinde de annesi Sultan Kadın'ın, Halil'in geyik avına çıkmaması için yakarması anlatılmaktadır. Halil isimli gencin geyik avlama tutkusuyla kendini ormana vurduğu; bir ara tevbe eder gibi olmasına rağmen avlamaktan vazgeçmeyerek geyiğin tuzağına düşüp hayatını nasıl mahvettiği konusu işlenmektedir (Kemal, 2016).

Türk kültüründe erken dönemlerinde geyikler de atlar gibi evcilleștirilmekte idi. Bugün hâlâ Ren geyiklerini evcilleștirip onlarla yaşayan; onları yük taşımada ve binek olarak kullanan Türkler vardır. Ren Geyiği Türkleri - Dukhalar kitabında bu konu detaylı olarak anlatılmaktadır (Küçüküstel, 2020).

Türklerin hem gereksinim hem de düşsel olarak geyiklerden kopamadıkları, Şekil 4 ve Şekil 5'te görüldüğü üzere geyik boynuzlarını at başlıklarında kullanarak bu geleneği sürdürmelerinden de anlaşılmaktadır. Savaşta at başlıklarında boynuzlar kullanarak atlara kut, ululuk ve güç aktarmışlardır. 


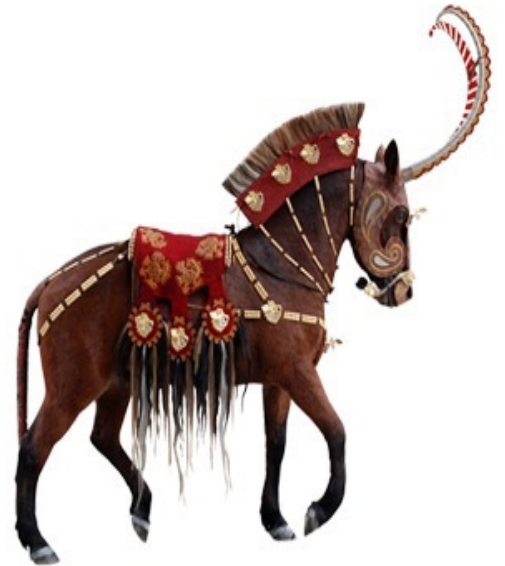

Şekil 4. Geyik Boynuzlu At Pazırık Kurganı M.Ö 500 (Youtube, 2016)
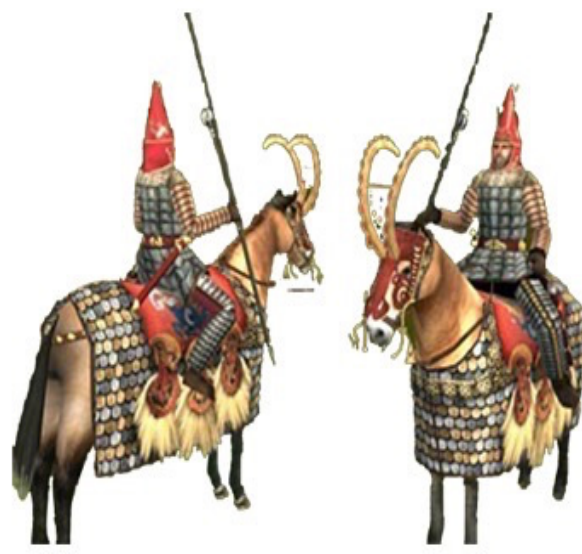

Şekil 5. Geyik Boynuzlu Atlarla Savaşa Giden Asker Temsili

Türk Alp ve Kağanlarının atlarıyla gömülmesi; öldükten sonra dirilecek olan Kağan'ı Tanrı'nın yanına taşıması için boynuzlu bir hayvan kurban edilmesi, İslamiyet'te Sırat Köprüsü'nden, kurban edilen koçlar üzerinde geçilecek olması ile benzerlik taşımaktadır (Youtube, 2016).

Geyik sembolü geçmișten günümüze yer aldığı efsanelerden menkıbelere, şaman ayinlerinden günümüzde ren geyikleriyle yaşamayı sürdüren Dukhalar'a kadar kutsal bir varlığı çoğu zaman da yol göstericiyi temsil etmektedir. Kimi zaman ayinde Şaman'ı göğe çıkaran gök hayvanı, kimi zaman da insanları ruhsal yolculuğuna çıkaran manevi bir araçtır. Geyiğin yol gösterici olması; bazen maddi, bazen de manevi kılavuzluğuna işaret etmektedir. Rehber olan geyik, maddi bağlamda belirli bir mekâna ya da sevgiliye giden yolu, manevi anlamda ise İslamiyet'e giden yolu göstermektedir (Parla, 2014, s. 865-884). Werner'in Hunlara yeni bir yurda doğru kılavuzluk eden geyik efsanesi bu çerçevede görülebilir. (Gök, 2019, s. 382).

\subsection{3. İslamiyet’te Geyik Sembolü}

Türk kültüründe önemli motiflerden biri olan geyik, İslami edebiyatımızda da geniş ölçüde yer almıştır. Kesikbaş, Güvercin, Ejderha, Hatun, Fâtıma Destanları gibi Geyik Destanı da halk arasında benimsenmiş ve mevlid kitaplarına ilave edilerek mevlidlerden sonra okutulmuştur. Türk-İslam literatüründe geyik destanı olarak bilinen "Dasıtân-ı Geyik" Hoca Sadrettin tarafından "Mesnevi" tarzında kaleme alınan dini-destani bir eserdir (Tören, 2005, s. 241). Bu eserde geyiğin Peygamber (a.s) ile konuşması ve sonunda 40 tane "kâfirin" Müslüman oluşu anlatılmaktadır.

İslamiyet'te tevhide varışın bir manevi yolculuk olduğu ve bu seferin de Hz. Peygamber'in miracı ile özdeşleştirildiği kaydedilir. İslam tasavvufi literatüründe miracın bir göğe yükseliş (uruc) süreci olmasından hareketle bu yolculuğun sembolik binekleri (rekîbe; çoğulu rekâib) olarak çeşitli kutsal(laştırılmış) hayvanlardan söz edilmektedir. Sufi ıstılâhlarında, mûcizât-ı rekâib bahsi (Metinlerle Tasavvuf Terimleri Sözlüğü, 2006, s. 542) içinde geçen bineklerin başında somut olarak at, soyut olarak da aşk şeklinde betimlenen Burak sembolünün; Peygamber'in Allah'a ulaşmasında manevi bir binek / vasıta olduğu görülmektedir. Ürkmez tezinde, Burak'ın fiziki özellikleri konusunda farklı ifadelere şu şekilde yer vermiştir:

"Metinlerde farklı şekillerde tasvîr edilen Burak, genel anlamda; lâl, zümrüt, inci, yakut, cevher, gümüş, altın, mercan anber, misk vb. gibi değerli maden ve kokulardan oluşan; at, eșek, katır, 
deve, tavus vb. gibi çeşitli hayvanlara benzetilen değişik renkteki farklı uzuvların bir araya gelmesi ile vücut bulmuş, iki kanatlı bir varlık olarak tanımlanabilir. Tasvîrlerdeki ortak özellik, Burak'ın yüzünün insan sûretinde olmasıdır" (2015, s. 178).

Bu tanımda Burak'ın ihtiva ettiği misk ile temsil edilen hikmet, aşağıda da açılandığı üzere aslında taşıdığı hikmet ile insanları peșinden sürükleyen geyiğin kan kesesindeki misk ile paralellik göstermektedir.

Geyiğin âdeta bir Burak gibi Türk -İslam coğrafyasında bir Veli kültüne tekabül ettiği kaydedilmektedir. Şöyle ki; şimdi anlatılacak Abdal Musa menkıbesi, geyik ile Veli'nin ne kadar özdeșleștiğini bize hatırlatmaktadır. Çünkü inanışa göre Veli'nin sahip olduğu metafiziksel hikmet; geyiğin karnındaki kan kesesinde mevcut olduğu düşünülen misk ile temsil edilmektedir.

Dil-güşâ adlı eserde ileride Kaygusuz Abdal olarak tanınacak Alâiye Sancak Bey'inin oğlu Gaybî Bey, henüz 18 yaşında iken bir ava çıktığı anlatılmaktadır. Av sırasında karşısında birden bir ahu belirir. Gaybî, ahuyu görür görmez hemen nişan alıp okunu atar ve onu sol koltuğunun altından vurur. Ama işin ilginç tarafı kanayan yarasına rağmen ahunun yere dahi düşmeden kaçmasıdır. Kaçarken de Gaybî̀yi peşinden sürükler. Uzun bir süre dağ tepe bu kovalamaca devam eder. Nihayet Gaybî, ahunun bir tekkeden içeri girdiğini görür ve hemen arkasından o da tekkeye girerek dervişlere geyiği sorar. Tekke Seyyid Abdal Musa'nın dergahıdır. Dervişler geyiği görmediklerini söyleyip gidip Şeyhlerine bu konuda ne yapmaları gerektiğini sorarlar. 0 da Gaybî̀yi yanına davet etmelerini buyurarak yanıtı bizzat kendi vermek istediğini söyler. Gâybi usûlü erkana uygun şekilde Abdal Musa'nın yanına varır ve olanları anlatır. Abdal Musa Gaybî̀ye okunu görürse tanıyıp tanımayacağını sorar. "Tanırım" cevabını aldıktan sonra kolunu yukarıya kaldırarak koltuğunun altına saplanmış olan oku gösterir. 0 anda Gaybî, ahunun aslında geyik donuna girmiş olan Abdal Musa olduğunu idrak eder ve hemen pişmanlık içerisinde özür dileyerek Abdal Musa'ya intisab eder (Güzel, 2009, s. 20-22).

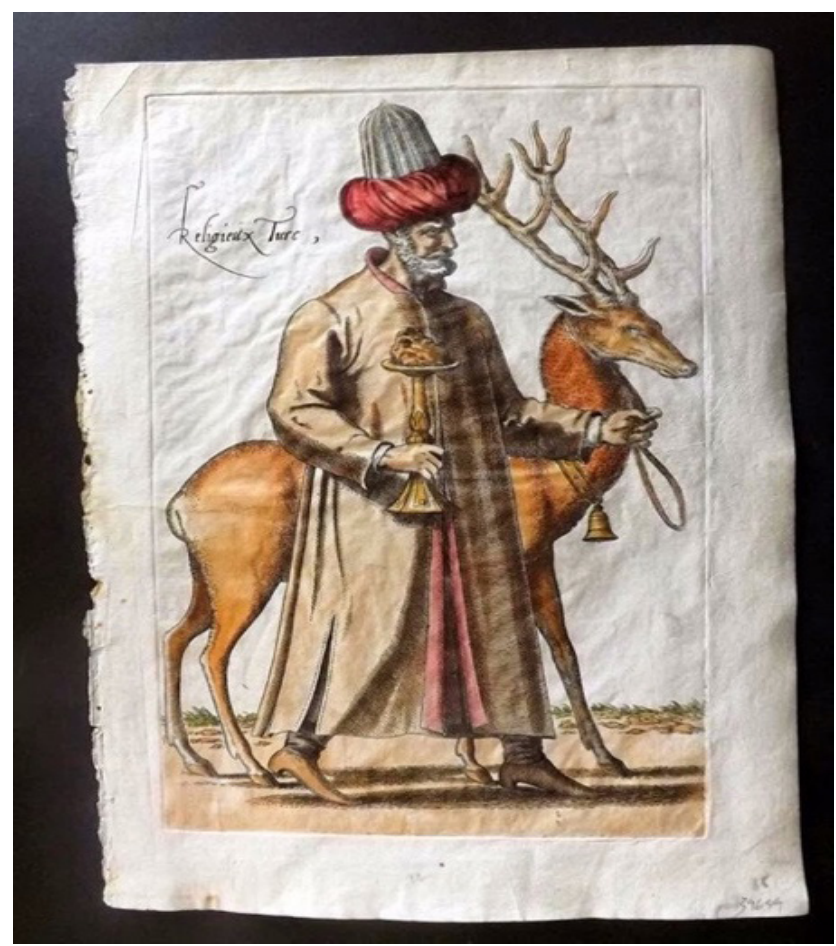

Şekil 6. Geyikli Baba (Sözümüz1.blogspot, 2019) 
Geyik - Veli birlikteliğinin kökenleri, şamancıl geleneklerini yukarıda işlediğimiz Orta Asya Türk dünyasında özellikle Belh hükümdarı İbrahim Ethem'in öyküsünde de kendini göstermektedir. Devamla tarihsel akış içerisinde benzer menkıbeler Anadolu coğrafyasında da taşınmıştır. Öyle ki; şamanın kutsal geyiği Anadolu'ya vardığında “müslümanlaşmış” hatta tasavvufi bir boyut kazanmıştır. Anadolu erenlerinin geyikgiller ile ülfeti açısından zikredilecek Türk Velilerinden biri de Bursa'daki Geyikli Baba'dır. "Türkiye’nin dinî-içtimaî tarihinin erken döneminin de en dikkat çekici simalarından biridir" (Ocak, t.y.). Orhan Gazi'nin Bursa'yı fethi sırasında Geyikli Baba da orduda bulunmaktadır. Bindiği geyiğin üzerinde savaștığından bahsedilmektedir. Şekil 6'da resmedilmiş olan Geyikli Baba'nın geyiklerle yürümesi ve dağlarda geyiklere binip dolaşması şaman gelenekleri ile de benzerlik göstermektedir. Altay Şamanlarının dualarında bindiğim hayvan geyik-sığın demeleri de bu benzerliği pekiştirmektedir.

Geyiğin boynuzları da geyiğin kendisi kadar anlam yüklüdür. Bu konuda geçmişten bugüne süregelen inanışlardan bazıları geyik boynuzunun insanları kötülüklerden koruması, hastalara iyi gelmesi, insanlara bereket, uğur getirmesi ve nazara iyi gelmesi şeklindedir. Günümüzde hâlâ bazı eski Anadolu evlerinin duvarlarına bazen de diş cephelerine geyik boynuzlarının ve kafalarının asılması geleneği sürdürülmektedir (Gavaz, 2016, s. 87-88). Kutsal olarak görülen geyiğin boynuzları Anadolu'nun ve Türk dünyasının çeşitli yerlerindeki türbelerde de bulunmaktadır. Hastaları şifalandırmada birer sağaltma aracı olarak kullanılmaktadır. Geyikler senede bir kez üreme dönemlerinde boynuzlarını düşürmekte ve yerine bir çatal fazlasıyla yenisini çıkmaktadırlar. Bu nedenle geyik boynuzları sembolizm olarak yenilenmeyi ve ölümsüzlüğü temsil etmektedir (Kumartaşlıoğlu, 2015, s. 137).

Türk mitolojisinde geyik; türeyiş unsuru olarak, av hayvanı olarak, yol gösterici olarak, şekil değiştirmek unsuru olarak, hükmedilen hayvan olarak, yer-su sembolü olarak, gök unsuru olarak bazense kötünün simgesi olarak ele alınmaktadır (Gök, 2019, s. 391).

\subsection{Batı'da Geyik Sembolü}

Yukarıdaki açıklamalar bize mit-mitoloji bağlamında sembollerin hikâyeleştirilerek gerek bireysel gerek kolektif bağlamda sosyal işlevselliğe sahip olduklarını yeniden hatırlatmıştır. Şöyle ki; bireysel olarak bu mit ve mitolojilere açık olan kitlelerde kimlik, kişilik ve ruh gelişimi açısından bilinç üstü ve bilinçaltı bir kodlama gerçekleştirmektedir. İkinci ve kolektif bağlamda ise hikâyeleștirilen hatta törenlerle dahası metafiziksel ayinlerle şekillere bürünen bu mitler hitap ettiği grubun kültürleşmesine ve sosyalleşmesine ivme kazandırmaktadır. Dolayısıyla nesilden nesile aktarımı sağlanan bu kadim bilgeliğin kuşaklar arasında geçişliliği masal-menkıbe-mesnevi literatüründe kendini bulmaktadır.

Şimdi sıra öykünün devamını Batı'nın tarihselliğinde aramaya gelmiştir. Bu bölümde geyikgillerin Batı kültürel uzamındaki mütekabil izdüşümleri irdelenecektir. Batı kültüründe geyik sembolizminin kökenlerinden bugüne gelişinde geçirdiği üç evre değerlendirilecektir. Bu bağlamda ilk önce Avrupa'nın mitolojik envanterindeki geyik olgusuna değinilecektir. Dolayısıyla Helenik ve onu takip eden Roma dönemlerindeki geyik sembollerinin bulunduğu göstergeler çözümlenecektir. Bunu takiben Hristiyanlığa geçişle geyiğin Azizlerle iletişiminin boyutları analiz edilecektir. İleriki bölümde Avrupalı kimliğinin modernite bağlamındaki ekonomik boyutu doğrultusunda Noel Baba'ya öykünme süreci daha anlaşılır hâle gelecektir. 


\subsubsection{Helen-Roma Avrupası'nda Geyik Sembolizmi}

Doğu kadim bilgeliğinde olduğu gibi Batı uygarlığının destanlarında da geyik sembolizmi görülmektedir. Geyik Batı destanlarında yabancı bir hayvan değildir; insanların antropolojik ortak mirasının mitlerinden bir tanesidir. Bu konuda Doğu'daki kültürel zenginliğe Batı'da rastlanmamaktadır. Bu da ayrı bir araştırma konusudur. Muhtemel sebeplerinden bir tanesi doğu kültüründe organik dünya görüşünün baskın oluşudur (Öke, 2015). Âdem canlı olduğu kadar âlemdeki bütün varlıkların da canlı olduklarına inanılır. Hatta simgesel olarak varlıkların derinlikleri organik dünya görüşünün vurguladığı metafiziksel âlem anlayışına uygundur.

Batı kozmogonisinde ilk karşımıza çıkan geyik miti Yunan mitolojisinde bulunmaktadır. Şekil 7'de Louvre müzesinde yer alan geyik ile heykeli görülmekte olan Artemis Ana Tanrıça olarak betimlenmekteydi. Gençlerin ve hayvanların en kritik zamanlarında karşılarına çıkarak kaderlerine hazırlanabilmeleri için onlara yardımcı olmaktaydı. Sadece bireylerin zor zamanlarında değil aynı zamanda devletlerin de sıkıntılı ve belirsiz durumlarında sığındıkları bir tanrıydı. Albayrak (2008), o dönemde sosyal yaşamda, kızların kaderinin kadın olmak, erkeklerin avcı ve asker olmak, vahşi hayvanların kaderinin avcılar tarafından avlanmak, büyük baş hayvanların kaderinin ise insanların yemeği olmak olduğunu anlatırken Artemis'in buradaki işlevinin bu geçiş dönemlerinde onları koruyup kollamak olduğunu ifade etmiștir. Buna ek olarak, bu özelliğinin onun mitoslarına da yansıdığını; bakirelere tecavüz edenleri ve hayvanları katledenleri cezalandırdığını, yokluk içindeki toplumları koruduğu örnekleriyle açıklamıştır (s. XIII-XIV).

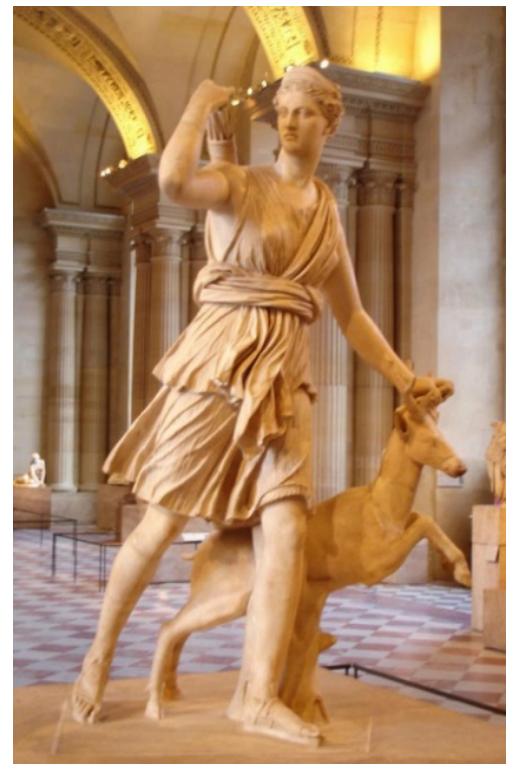

Şekil 7. Artemis- Louvre Müzesi (Okuryazarim, 2018)

Keryneia Geyiği adlı büyük geyik, mitolojide Avcılık Tanrıçası Artemis'in kutsal hayvanıdır. Altından boynuzları ve tunçtan ayakları olan bu dişi geyiğin yorulmak bilmeyen bir hayvan olduğu söylenir (Doğanay, 2010).

Aynı düşünce yapısındaki bu mitin Roma mitolojisine aktarıldığı görülmektedir. Burada da Diana üzerinde durulmaktadır. Diana, Roma mitolojisinde avcılığın bakire tanrıçası olarak anılmaktadır. Diana, Yunan mitolojisinde Artemis'e denk sayılmaktadır. Diana'nın güç hayvanı olarak karşımıza yine geyiğin çıktığı görülmektedir ve buna ek olarak dişi ayı da sembol hayvanı olarak belirtilmektedir (Wikipedia, t.y.). 
Geyik figürünün yeniden antropolojik önem kazanması nerede ve ne zaman Avrupa'da gerçekleşmiştir diye sorgulandığında karşımıza sınırlı bir literatür çıkmaktadır. Görünen odur ki; 19. Yüzyılda Avrupa kültür ve sanat dünyasında romantizmin ortaya çıkışı ve gelişmesi sonucunda doğaya vurgu yapılmasıyla başta geyik olmak üzere hayvanların yeniden masalımsı literatüre geçtiği görülmektedir. Efsanelerin müzikalleştirilerek operalara konu olması yine bu dönemin ürünüdür. Bu bağlamda geyik, milliyetçilik düşüncesinin dinsel boyut kazandığı 19. yüzyıl Almanya'sında Richard Wagner'in operalarında görülmeye başlamıştır.

\subsubsection{Hristiyanlık, Azizler ve Geyik}

Şekil 8 ve Şekil 9'da kaydedilen iki görselde ilk kez Hristiyan dünyasında ruhban-geyik ilişkisi ortaya çıkmaktadır. Şekil 8'deki resimde Aziz Giles'in elinde ok saplı olması, Şekil 9'da ise geyiğin iki boynuzu arasında Hz. İsa'nın çarmıha gerilmiş görüntülenmesi oldukça ilginç sembolizmalardır.

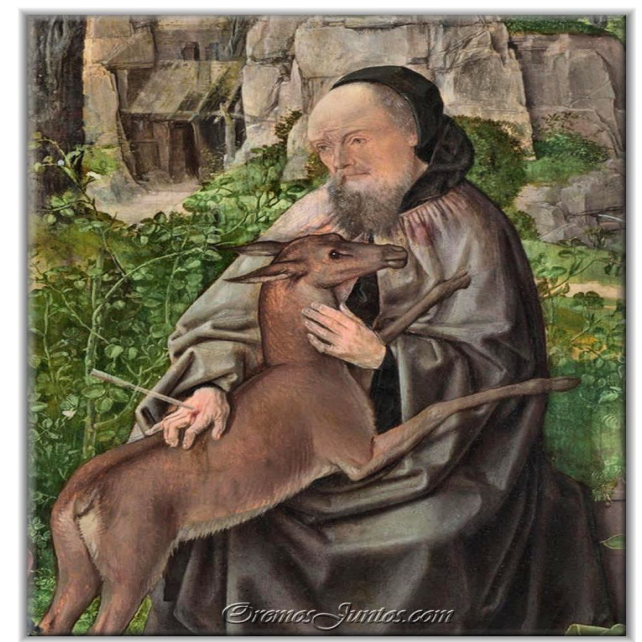

Şekil 8. Saint Giles ve Geyik (Anastpaul, 2019)

Aziz Giles asil ve varlıklı bir ailenin çocuğu olarak dünyaya gelmiştir. Hayatını ihtiyacı olan fakir insanlara adamıştır. Yunanistan'ı terk ederek Güney Fransa'da Septimania'daki Gard nehri kenarında yaşamıştır. Bir efsaneye göre Tanrı kendisine sütüyle beslenmesi için bir geyik yollamıştır. Aziz Giles tek arkadaşı olan bu geyik ile Nîmes yakınlarındaki ormanın derinliklerine çekilmiştir. Kralın avcıları bir gün geyiği avlamak üzere takip ederlerken Aziz Giles'in yaşadığı mağaraya ulaşmışlardır. Geyiği avlamak isterlerken attıkları ok ile Aziz Giles'i de yaralamışlardır. Daha sonra bu ok ile vurulan Aziz Giles, fiziksel engellilerin hamisi şifagüder biri olarak anılmıştır (Catholicsaints, t.y.). 


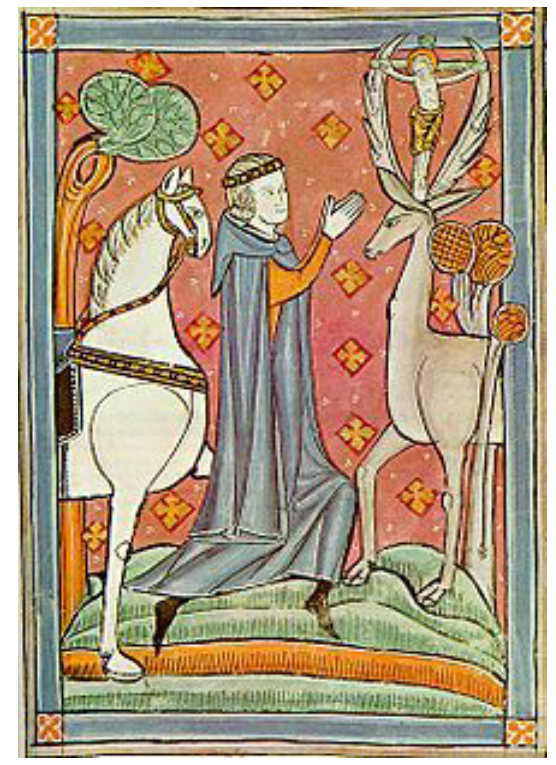

Şekil 9. Aziz Hubertus (Wikipedia, t.y.)

Bir Hristiyan Aziz'i olan Hubertus'un yer aldığı Şekil 9'da, bir geyiğin boynuzlarında çarmıha gerilmiş olarak İsa figürü görülmektedir. Aziz'in arkasında yine kadim kültürde kutsal bir hayvan olan at yer almaktadır. Saint Hubertus avcıların, matematisyenlerin, metal işçilerinin koruyucu azizi olmakla birlikte kuduza kür bulmaya çalışan bir insandır.

Efsanede, Hubertus'un, boynuzları arasında Hz. İsa'nın gerilmiş olduğu bir çarmıh bulunduran geyik ile karşılaşmasıyla; dünyevi bir aristokrattan manevi hayat süren bir Aziz'e dönüşümü anlatılmaktadır. Sadık kilise müdavimlerinin kiliseye akın ettikleri bir cuma günü, Hubertus, Ardennes'in ormanlık bölgesinde av peşindeydi. Muhteşem bir geyiği öldürmek için takip ederken, bir anda geyiğin doğrudan ona döndügünü ve görkemli boynuzlarının arasında asılı duran parlak bir haçı açığa çıkardığını gördü. Bu sırada Hubert gökten “Tanrı'ya dönüp kutsal bir yaşam sürmezsen, hemen cehenneme gideceksin" şeklinde bir ses duydu. Bunun üzerine ne yapması gerektiğini sordu ve Tanrı kendisinden Piskopos Lambert'i aramasını istedi (County Deers Talking, 2019). Hubert de sözünü tuttu. Piskoposu Lambert'e gitti, onun korumasını istedi ve hayatının geri kalanını Tanrıyla geçirmek istediğine dair güvence verdi. Piskopos kutsamasını verdi ve onu kurtuluş yoluna koydu (Les Compagnons De Saint-Hubert, t.y.). Aslında bu mucizevi olayla Aziz Hubertus, kalbinin dönüşmesi ve Azizlik hayatına geçişi ile bir Hristiyan efsanesinin öznesi hâline gelmiştir.

Burada asıl önemli olan geyik mitinin Noel Baba ile birlikte uzak Batı denilen Amerika'da ortaya çıkışının hangi verilerle izah edileceğidir.

\subsubsection{Geyik Mitinin Amerika'ya İntikali}

Geyik mithosu Kızılderililer tarafından uzak Batı'da yani Amerika'da fazlasıyla işlevsel bir mitolojik dokuya sahiptir. Batı uygarlıklarının orta çağ öncesi efsanelerinden operalarına kadar geyik miti bulundurduğu görülmektedir. Batı'da da geyik sembolüne Doğu'dakine benzer anlamlar yüklenmiştir. Geyik miti Amerika'ya taşındıktan sonra Amerika'nın kendi kültürel coğrafyası içerisinde yerini almıştır. Bu geyik mitine ve onun Noel Baba ile bağdaştırılmasına ilişkin ilk gördügümüz görsel iç savaş sırasında çizilmiş olan bir karikatürdür. Amerikan iç savaşı sırasında Harper's Weekly dergisinin 3 Ocak 1863 tarihli sayısı için yapılan çizim Şekil 10’da görüldüğü üzere, "Santa Claus Ordugah”ta başlı̆̆ı ile yayınlanmıştır (Öğüt, 2013). 
Şekil 10'daki karikatürde Noel Baba siyahi olarak nitelendirilmektedir. Bu görselde Santa Claus'u, geyik figürünü ve hediyeleri görmekteyiz. Ama henüz Santa Claus yani Noel Baba ile geyiklerin Amerika'nın kendi tarihi içerisinde yerli yerine tam olarak yerleşmediği söylenebilir. Daha sonraki aşamada ise Noel Baba'nın ortaya çıkışı yılbaşı dolayısıyla olmaktadır. Özellikle zamanlama olarak yılbaşının seçilme nedeni ise; yeni yılın bir şekilde yeniden doğuş, yaratılış, her şeyin bir dönüm noktası, çıkış noktası olmasıdır. Zamanlama olarak yeni yll seçildikten sonra geyik figürü ile birlikte Noel Baba efsanesinin ticari bağlamda oluşturulduğu görülmektedir.

Bu kıtada ortaya çıkan yeni uygarlık tüketim endekslidir. Neoliberal kapitalizmin egemen olduğu, çarkların olduğu bir uygarlık söz konusudur. Dolayısıyla kendisine mahsus fablları, mitleri ve mitolojisinin olması gerekmektedir. Hedef, bir tüketim toplumu mitolojisi üretmek olunca en fazla yararlandıkları Nasrani bir figür olan Father Nicholas ve daha arkaik olan geyik sembolüdür. Dolasıyla tam Batı'nın kültürel kökenlerine doğru bir dönüş bulunmaktadır. Oradaki malzeme alınıp yeniden üretilerek günün ekonomik ideolojisine uygun bir ikon hâline getirilme çabası görülmektedir.

Günümüzde ticari bir simge hâline gelen Noel Baba, yıllardan beri anlatılan mitolojik Santa Claus karakteriyle bütünleştirilerek yepyeni bir varlık hâline gelmiştir. Bu mitin ticarileşmesinde Coca-Cola markasının arayışı da rol almaktadır. Bu arayıșa markanın yaşadığı bir sıkıntı yol açmıştır. Kolanın içeriğinde kokain bulunması nedeniyle CocaCola markasının reklamlarında çocuk kullanımı yasaklanmıştır. Bunun yanı sıra sıcak günlerde sıklıkla içilmek için üretilmiş soğuk bir içecek olarak lanse edilen kola, tüketim okazyonunu genişleterek kışın da tüketilmeyi hedeflemektedir. Bu süreçte marka, kampanyasında Noel Baba'yı kullanmaya başlayarak Noel Baba ile oluşturduğu mitin günümüze kadar intikalini sağlamış, çocuklarla olan ilişkisini de bu mit üzerinden tekrar inşa etmiştir. (Ersoy, 2008, s. 8).

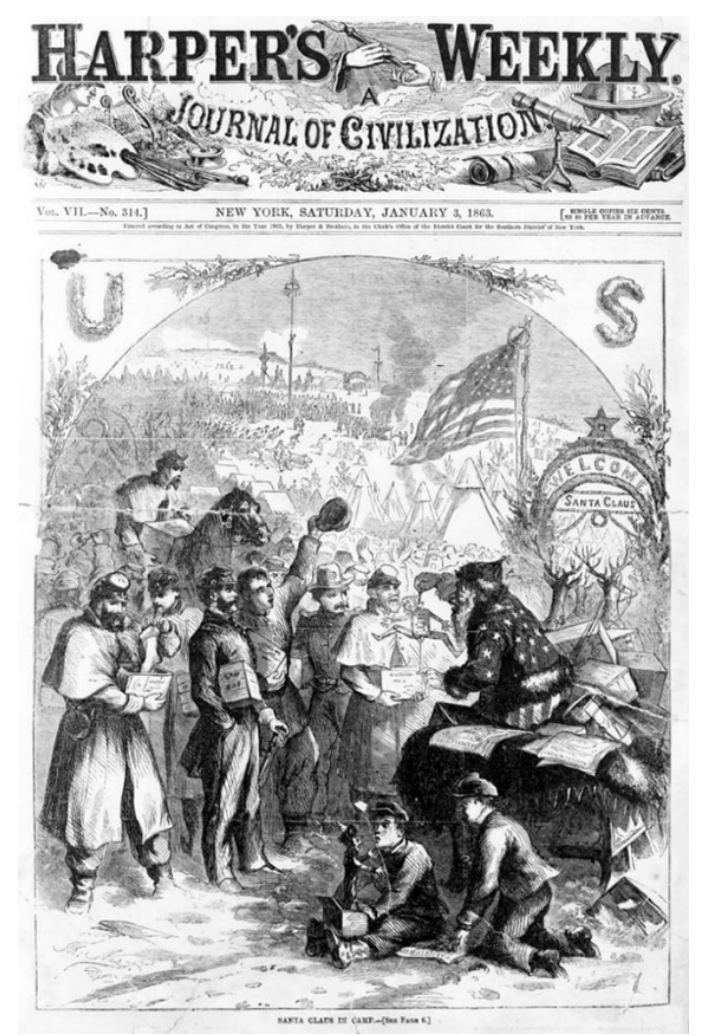

Şekil 10. Santa Claus’un ilk çizimi (Öğ̈üt, 2013) 
Noel Baba ilk olarak karikatürist Thomas Nast tarafından Şekil 10'da görüldüğü üzere siyah-beyaz olarak resmedilmiştir. Daha sonra 1924 yılında Coca-Cola firması için reklamlar tasarlayan Haddon Sundlom'un çizimleri ile kırmızı-beyaz elbiselerini giymiştir. Bu noktadan sonra Noel Baba mitolojik Santa Claus karakteriyle bütünleşmiş ve sonrasında yılbaşı kutlamalarının yaygınlaşması gerçekleşmiştir. Böylece Coca-Cola markası dünya tüketim endüstrisini en üst seviyeye taşıyan bir marka miti oluşturmuştur (Ersoy, 2008, s. 7-8).

Ersoy'un (2008) çalışmasında bulunan aşağıdaki ifadesini destekler şekilde Coca-Cola markasının, sembolizmi kadim bilgelikten ithal ederek mitin doğasına uygun bir model oluşturduğu ve bir dizi ritüeli her sene aynı zaman diliminde tekrar ederek mitsel davranışı pekiştirdiği yılbaşı kutlamalarında görülmektedir: Ersoy bu durumu Eliade'nin tespitlerine dayanarak şöyle alıntılamıştır: “... insan ötesi bir modelin taklit edilmesi, örnek oluşturan bir olgular akışının yinelenmesi "mitsel davranış"ın başlıca belirtilerini oluşturur" (Ersoy, 2008, s. 6) .

Yllbaşı konsepti irdelediğinde farklı kutlamalardan değişik sembol ve ritüelleri içeren ilginç bir sentez olduğu görülmektedir. Öncelikle her sene 24 Aralık'ta kutlanan Noel'den, bu mitolojinin kahramanı olan Noel Baba alınmıştır. Bunun yanı sıra posterlerde sıkça yer alan geyikler, hediyeleșme kültürü ve yılbaşı ağacı sembolü de yılbașı ile bütünleştirilmiştir. 26 Aralık'ta kutlanan Şükran Günü'nün akla ilk gelen yemeği olan hindi de konsepte dahil edilmiștir. Aile veya arkadaşların 31 Aralık gününde yeni yılı kutlamak amacıyla bir araya gelmeleri de yılbaşı ritüelinin vazgeçilmezlerinden biri hâline gelmiştir.

Amerika gibi bir toplumda kapitalizm, her zaman insanları tüketime yönlendirecek sembollere ihtiyaç duymaktadır. Markalar bunu yaparken geçmişteki mitlerin mistik güçlerinden yararlanmaktadırlar. Noel mitine bakıldığında geçmişteki Aziz - Geyik hikâyelerinden yola çıkıldığı/esinlenildiği görülmektedir. Mitolojinin doğasında olan ritüeller burada da kadim semboller ile kapitalizme alet olacak şekilde yeni kahramanlarla tekrardan yapılandırılmaktadır. Noel Baba'nın henüz tam ticarileşmemiş, bir başka deyişle daha masalsı resmedilmiş hâli Şekil 11'de görülmektedir.

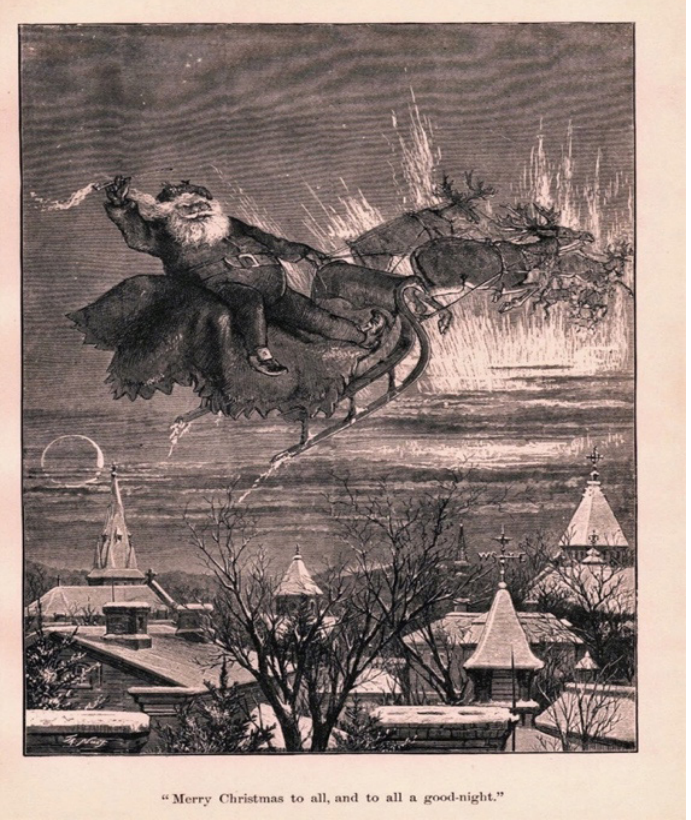

Şekil 11. Merry Christmas to all, and to all a good-night", Harper's Bazaar, Ocak 4, 1879 (Morristown \& Morris Township Library, 2013) 
Noel miti ticarileștirilirken daha fazla tüketmeye yönlendirmek üzere içine hediye kültürü de yerleştirilmiştir. Bunun için zamanlama olarak hediyeleşmenin en yoğun olduğu Christmas dönemi seçilmiştir. Mitolojideki kahraman veya tasavvuftaki menkıbelerdeki ermiş rolüne burada Father Nicholas seçilmiştir. Çünkü Demre'de oturan Father Nicholas çocuklara geceleri fark edilmeden hediye veren yardımsever bir Aziz, Papaz'dır.

Dinsel mitin Noel için incelikle işlendiği görülmektedir. Dinsel bir unsur olarak Noel Baba'nın üzerine bir cübbe giydirilmiştir. Kıză̆ını çekme rolüne ise mitolojide Tanrı'nın hayvanı olarak anılan geyik seçilmiştir. Noel Baba geyikleriyle birlikte hediyeleri (maddi ve gökyüzünden toparladığı manevi hikmetler) dağıttıktan sonra gökyüzünde seyretmektedir. Özetle ifade edilecek olursa burada; dinsel bir motifin seküler hâle getirilip ticarileşmesi söz konusudur.

\section{Göstergebilimsel Çözümleme}

$\mathrm{Bu}$ bölümde yukarıda verilen literatür doğrultusunda geyik sembolünü içeren Hacı Bektaş-i Veli ve Noel Baba'nın bulunduğu iki görselin okunması gerçekleştirilecektir. Görsellerde ve metinde hem simgesel hem de metinsel olarak bazen geyik bazen de ceylan kullanılmaktadır. Görsellerin okunmasında Göstergebilim kuramı esas alınmıştır.

Gösterge olarak sunulan iki görsel; gösteren ve gösterilen boyutları dikkate alınarak çözümlenmiştir. Buna ek olarak Barthes'ın geliştirdiği göstergebilim yaklaşımından faydalanılarak mit ve yan anlam bağlamında kültürlerarası bir okuma yapılmıştır.

Çözümleme işlemi için kullandığımız göstergebilimsel yöntemden, görselleri çözümlemeye geçmeden, kısaca söz etmek uygun olacaktır. Göstergebilim dilimizde özellikle dilbilim (Fransızca linguistique) sözcügü örnek alınarak üretilmiştir. Göstergebilim (Fransızca semiotique ya da semiologie) terimi öncelikle "göstergeleri inceleyen bilim dalı" ya da "göstergelerin bilimsel incelenmesi" olarak tanımlanmaktadır. Kısacası; göstergeleri inceleyen bilim dalıdır. Gösterge ise kendi dışında başka bir şeyi temsil eden ve temsil ettiği şeyin yerini tutabilecek özellikte olan her çeşit biçim, nesne, olgu, vb. olarak açıklanmaktadır (Rifat, 2009, s. 11).

Çağdaş göstergebilimin Avrupa'daki öncüsü Ferdinand de Saussure'dür. Saussure'ün dilbilim kuramı 19. yüzyılda meydana gelmiş en önemli gelişmelerden biri olarak anılmaktadır. Güngör'ün de kaydettiği gibi Saussure'e göre "dil bir göstergeler sistemidir. İnsanlar arasında iletişimin sağlanması ise çeşitli gösterge sistemlerinin kullanılmasıyla olanaklıdır. Bu değinisiyle Saussure yalnızca dilbilimin kuruculuğunu yapmakla kalmamış, aynı zamanda göstergebilimin de temellerini atmıștır" (2018, s. 236). Saussure'un dilsel göstergesi iki bölümü ihtiva etmektedir. Bunlardan biri gösteren diğeri ise gösterilendir. Zihnimizde meydana gelen soyut kavram ve imge; "gösterilen" olarak tanımlanmaktadır. "Gösteren" ise gösterilenin ses ile ifade edilen somut şekli olarak ifade edilmektedir. Göstergeyi oluşturan bu iki olgu, birbirine bağlı ve kendi içerisinde birbirinden ayrılamayacak şekilde bir bütünlük arz etmektedir (Güngör, 2018, s. 236).

Seçilen göstergelerin arka planındaki mitsel göndergelerin yoğunluğu nedeniyle anlamlandırmada Göstergebilim'in kurucu isimlerinden ve postmodern düşüncenin kurucu öncülerinden sayılan Roland Barthes'ın Göstergebilim yaklaşımından faydalanılmıştır. Barthes'ın yapısalcılıktan postyapısalcılığa uzanan entelektüel açlımı bulunmaktadır. Bir yandan postmodern felsefenin kurucuları arasında yer alırken, diğer yandan postmodern düşüncenin en özgün kuramcılarından biri olarak anılmaktadır. 
Küreselleşen dünyamızda kapitalizmin güncel toplumsal mitler ürettiği Barthes'ın da gözünden kaçmamıştır. Öyle ki; yazılarının pek çoğunda popüler kültürün ekonomi odaklı ideolojik mitlerine eğilmekten kendini alamamıştır (Barthes, 2018). Yaylagül'ün de vurguladığı gibi "Kapitalist toplumdaki mitler egemen yapıyı doğallaştırır ve meşrulaştırır. İnsanların kimlerle özdeşleşeceklerini ve nelere karşı çıkacaklarını belirler. Bu mitler kitleleri baştan çıkarır ve birer taklitçiye dönüştürür" (Yaylagül, 2019, s. 123). Barthes'ın söyleminde mitlerin anlamlandırma sürecinde tüketicilerin ya da izleyicilerin de belirleyici işlevleri bulunmaktadır. Yine Yaylagül'ün (2019) kaydettiğine bakılırsa "Semiyoloji mitlerin kodlarını açığa çıkaracaktır. S/Z'de metinleri okur odaklı (the readerly) ve (the writerly) yazar odaklı olarak ayırır" (s. 124). Devamen, Barthes'a atıfla, Yaylagül (2019) konuyu şöyle özetlemektedir: "Çağdaş popüler kültür açık uçlu mitlerden oluşur. İzleyiciye haz verir. Her izleyici kendi hazzını üretir. Burada postyapısalcı yaklaşımın temelleri bulunmaktadır. Bu hazda cinselliğe vurgu yapılır. Böylece Barthes, alımlama çalışmalarının öncülüğünü de yapmıştır" (s. 124).

Güngör'ün (2018) de belirttiği üzere; Barthes'ın çözümlemelerinde vurguladığı bir başka kavram yan anlamdır. Barthes, yan anlam kavramıla mitleri kastetmektedir. Mythologies (1957) adlı eserinde göstergelerin bilhassa mitsel anlamlarına odaklanır (s. 254). Dolayısıyla, Barthes'ın günümüz mitleri üzerindeki okumaları, bu makalede seçilen görsellerin mitsel boyutta okunması konusunda fayda sağlamıștır.

Göstergenin gösteren boyutları Greimas'ın eyleyenler modelinden hareketle uzam ve eyleyen olmak üzere iki ana bölümde irdelenmiştir. Çözümleme esnasında simge çözümlemesi yapılırken daha çok Greimas'ın eyleyenler yaklaşımından faydalanılmış ve eyleyen kavramına tutunulmuştur. Greimas'ın eyleyenler kuramında varlık ya da nesnenin gerçekleştirdiği eylem önemlidir. Bu nedenle eyleyen kavramı kişi olgusunun çok daha ötesindedir; çok daha geniş kapsamlı ve kuşatıcıdır. Kıran ve Kıran (2011), bu kavramı aşağıdaki ifade ile özetlemektedir:

"İnsan da olabilir, nesne de, tekil de olabilir, çoğul da, somut da olabilir soyut da. Öte yandan, gene eylemin ya da işlevin önde gelmesi nedeniyle ve gerçekleşme düzleminde tek bir varlık ya da nesne olarak tanımlanan bu öğe, içerik düzleminde birkaç eyleyenin ișlevini birden yüklenebilir, bașka bir deyișle, aynı zamanda birkaç eyleyenin karşıllğı olabilir. Bunun sonucu olarak eyleyeni bir varlıktan çok belirli bir 'bağıntının bir öğesi' olarak tanımlamak gerekir” (2011, s. 272).

Göstergebilimsel yöntemi kısaca betimledikten sonra, seçtiğimiz iki görselin simgesel okunmasına geçebiliriz.

Bu makale için görsel okuma yapmak üzere seçilen görsellerin birinde kola içen bir Noel Baba görünmektedir. Ancak burada asıl vurgulanmak istenen nokta Noel Baba'nın beraberinde anımsadığımız geyik figürüdür. Bir tüketim toplumu ikonu hâline gelen Noel Baba'nın, geyik ile ilişkisi bugüne değin yeterince araştırılmamış ve metafiziksel arka planı hakkında çalışmalara rastlanmamıştır. Bu çalışma geyik mitinin kadim bilgelikten popüler kültüre uygulanışını kıyaslamalı bir metotla incelemek üzere yola çıkmıştır.

\subsection{Hacı Bektaş-i Veli Tasviri}

Hacı Bektaş-i Veli'nin resmi bize Türk-İslam kadim geleneğindeki geyik-insan iletişimini, dünyaya bakış açısını ve bunun kişinin kimlik ve ruh aynasında nasıl bir yere sahip olduğunu göstermesi açısından çok temsili özelliklere sahip bir görseldir. 


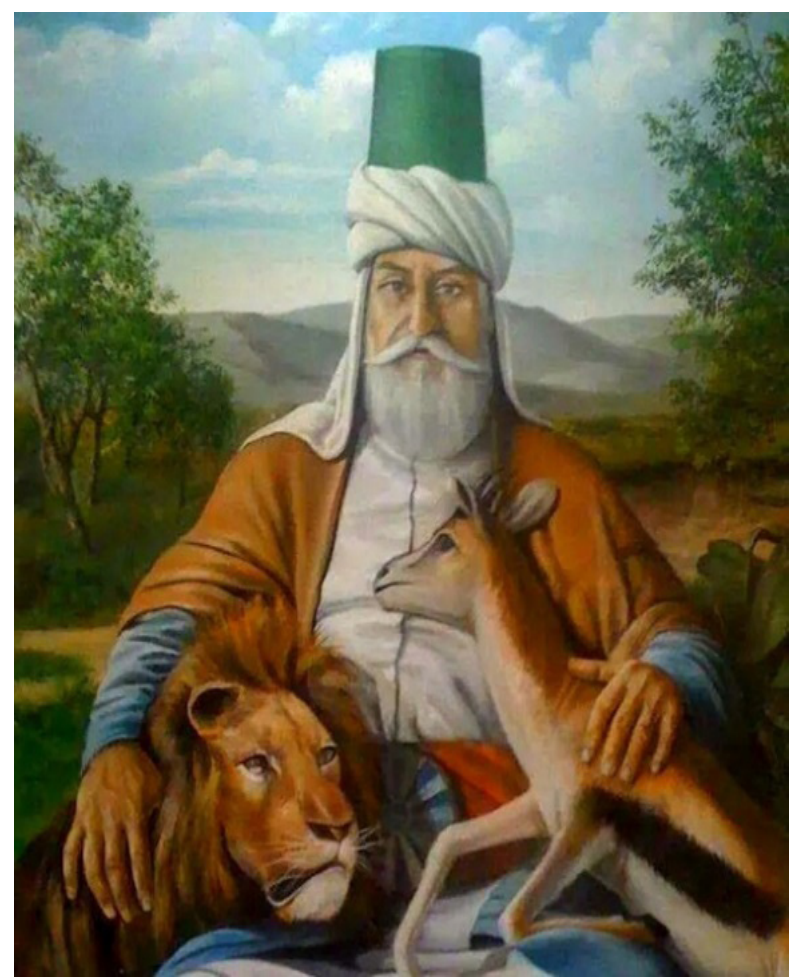

Şekil 12. Hacı Bektaş-i Veli (Cem Vakfi, 2017)

Hacı Bektaş-i Veli Orta Asya'dan gelmiştir. Oradaki tasavvufi akımların içerisinde en eski olan Hoca Ahmed Yesevî̀nin öğretisinden etkilenmiştir ve O’nun öğrencilerinden biridir. Oradan belli bir direktif ile Anadolu'ya gönderilmiş. Anadolu'nun müslümanlaştırılmasında önemli bir yere sahip olmuştur. Görselde eyleyenler olarak Hacı Bektaş-i Veli, geyik ve aslan incelenirken uzam olarak nebat ve cemâd irdelenmektedir.

Şekil 12'deki resmin arkasında bir kırsal alan olduğu görülmektedir. Bu kırsal alan tabiatla iç içe olan Kırşehir yani bugünkü Hacı Bektaş kasabasıdır. Arka plandaki kırsal alan ile Hacı Bektaş-i Veli'nin doğa ile iç içe olduğu gösterilmektedir. Uzamdaki doğa vurgusu ile Hacı Bektaş-i Veli'nin organik ve ekolojik dünya görüşü yansıtılmaktadır.

Eyleyen olarak Hacı Bektaş-i Veli ile gösterilen Allah'ın Azizi oluşudur. Üzerinde tarikat sembollerinin bulunduğu derviş kıyafeti bulunmaktadır. Başındaki sikke, dervişe her an ölümü hatırlatan mezar taşını, yeşil sarık Hacı Bektaş-i Veli'nin manevi konumdaki nurunun seviyesini belli etmektedir. Sikkenin etrafındaki destarın beyaz olması belli bir safiyete sahip olduğunu göstermektedir. Belindeki kemerde bulunan teslim tașı, Hacı Bektaş-i Veli'nin Allah'a teslimiyetinin işaretidir. Gözlerinin çekik olması Orta Asya'dan geldiğini anlatmaktadır. Üzerinde kaftanı ve yensiz yakasız gömleği dervişliğinin görsel ifadesidir. Bağdaş kurmuş bir şekilde hiçbir yere yaslanmadan oturmaktadır. Uzamda zamana ait bir obje kullanılmayarak her zamana ait olabilecek "lâ zaman" bir his verilmektedir.

Bu görselde eyleyen olarak Hacı Bektaş-i Veli'nin sol yanında geyik, sağ yanında ise aslan bulunmaktadır. Geyiğin en önemli özelliği mitolojide Tanrı'nın hayvanı olmasıdır. Sıfat olarak bakıldığında ise ceylan çok cemalidir. Bu da aslen Hacı Bektaş-i Veli'nin bir yanıyla kalbinin tarafında tuttuğu ceylan gibi cemali vasıfları olduğuna işaret etmektedir. Ceylan ile diğer gösterilenler ise mitolojideki derin işlevinde olduğu gibi manevi Burak ve asırlar boyunca hep peşinden koşulmuş olan Veli kültü, ilim, hikmet ve irfan temsili olmasıdır. Hacı Bektaş-i Veli'nin sağ tarafında ise celâli vasfı olan ve tasavvufta Hz. Ali'yi 
de sembolize eden aslan bulunmaktadır. Aslan Hacı Bektaş-i Veli'nin kılıç tutan elinin altında yer almaktadır. Hacı Bektaş-i Veli'nin gerektiğinde Hz. Ali gibi nefsi için değil; hak ile batılı ayırmak için kılıcını kullanması, zülfikar temsilini de hatırlatmaktadır. $\mathrm{Bu}$ görselde aslan ile geyiğin Hacı Bektaş-i Veli'nin kucağında yan yana olması hem cemali hem de celâlinin bir arada bulunduğu bir İnsan-ı Kâmil portresinin ifadesidir.

Burada bir başka gösterilen mana ise geyik ile aslanın dost olabileceğidir. Bu görsel, farklılıklara rağmen bir arada yaşanabileceğini gösteren barış ve dostluk temsilidir. Hacı Bektaş-i Veli her ikisine de kucaklamaktadır. Bu da insanın bencilleşmesine yönelik bazı çıkarsamaları beraberinde getirmektedir. Şöyle ki, bu görselde insanların maneviyatına daha çok önem verildiği gösterilmektedir. Uzamda cemâd olarak bulunan dağlar ve nebat olarak bulunan ağaçlar yer almaktadır. Ekolojiye; insana, hayvanlara, âleme daha fazla önem verilmektedir. 21. Yüzyılın bugünkü ekolojiye hasmane egemen tavrına karşı daha organik bir dünya görüşünü içeren bir alternatif bakış açısı yansıtılmaktadır.

\subsection{Noel Baba Posteri}

Şekil 13'de alışılagelmiş bir Noel Baba temsilinin dışında farklı bir Noel Baba posteri görülmektedir. Görselde Noel Baba'nın beyaz sakalı vardır ama daha özensiz ve dağınıktır. Burada da yine ceylan bulunmaktadır. Ceylanın konumlanış ve duruş şekli ve Noel Baba'nın hâli; Batı uygarlığının hem Nicholas'ı hem de geyiği nasıl dönüştürdüğünü ifade etmektedir. Eskiden geyikler insanları yönlendirirken burada eyleyen olan geyik ikinci plana düşmüş, Noel Baba'nın ayaklarının yanında, korunmaya muhtaç hâle indirgenmiştir. Dahası manevi bir Burak'tan maddi bir araca dönüştürülmüştür. Bu da Batı uygarlığında insanının tabiata egemen oluşunun görüntüsüdür. Eyleyen olarak Noel Baba'nın çok rahat bir koltukta oturmuş olması artık Baba Nicholas'ın bu tüketim topluluğundan mutluluğunu göstermektedir. Elinde bir kola, kolunda saat ve bir Peder'den beklenmeyecek gayri ciddilikte bacak bacak üstüne atmış, insanların yeni yılını kutlamaktadır. Sonuç olarak burada dinsel bir mitin kahramanının mutasyona uğratılarak Amerikan kapitalizminin ikonu hâline getirildiği görülmektedir. Noel Baba'nın kırmızı cübbesi ile gösterilen Coca-Cola'nın kurumsal renkleri, Amerikan bayrağının kırmızısı, dinamizm ve kan manalarını içeren kapitalizmin cübbesidir.

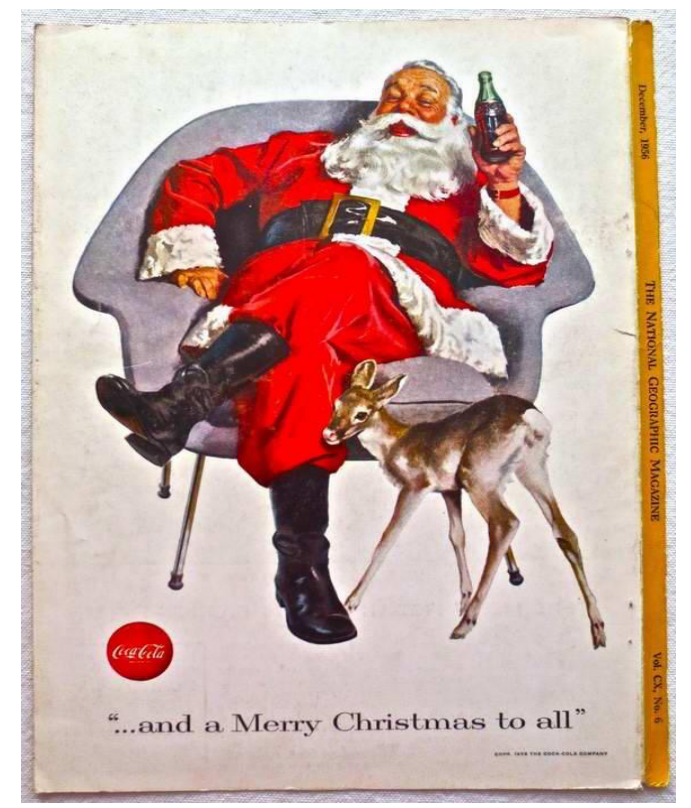

Şekil 13. Coca Cola Posteri, 1956 (Öğüt, 2013) 
Uzama baktığımızda beyaz bir boşluk ve cemâd olarak da gri metal ayaklı 20. Yüzyıla ait son derece modern bir koltuk görülmektedir. Göstergebilimsel bağlamda beyaz bir boşluk ve gri metal ayaklı modern bir koltuk ile gösterilen artık Noel Baba'nın doğadan ve doğallıktan tamamen kopması, dolayısıyla mekanik dünya görüşünün temsili hâline gelmesidir. Koltuk ile diğer bir gösterilen ise zamandır. Artık Noel Baba bir kızakta değildir. 20. Yüzyılı çağrıştıran metal mekanik dizayna sahip bir koltukta oturmaktadır. Etrafta nebat bulunmamaktadır. Ancak yine de Noel Baba'nın görseli, somut olarak posterde yer almasa da Noel ağacını da çağrıştırmaktadır. Hacı Bektaş-i Veli'nin görselindeki nebat canlı iken, Noel ağacı denilince genel olarak akla gelen suni süslerle donatılmış olan yapay bir ağaçtır. Bu çağrışım da sekülerleşme ile ekolojiden kopuşu ve mekanik dünya görüşüne geçiş tespitini pekiştirmektedir. Göze çarpan diğer bir cemâd ise Coca-Cola şişesidir. Yaptığı ticari çağrışımla Şekil 14'teki vurguladığımız mekanik devirde insanı paraya doğru yönlendirilmektedir. Şekil 14'te ifade bulan döngü bu mekanikleşme sürecine tercümanlık etmektedir.

Bilindiği gibi kapitalizmin motoru protestan etiğidir (Weber, 2014). Protestan etiğinde de çalışan insanın yani üreten ve tüketen insanın ekonomiyi canlandıran bir unsur olarak âdeta Hristiyanlığın protestan kanalı ve yorumunca kutsandığı üzerinde durulmaktadır. Dolayısıyla burada bu düşüncenin altını çizmek için bir dinsel öğe kullanılması düşünülmüştür. Bu nedenle Baba Nicholas olarak Santa Claus seçilmiştir. Santa Claus, yeni nesillere bu tüketim toplumunu benimsetmesi için önemlidir. Çünkü Santa Claus çocukları çok sevmektedir. Yeni nesillerin de böyle bir yönteme alıştırılması için Nicholas uygun görülmüştür.

İki görsel karşılaştırıldığı vakit ilginç olan ikisi de Anadolu'daki ikonlardır. Biri Antalya diğeri ise Kırşehir'dedir. İki göstergenin arasında mana olarak zitlaşan bir simetri bulunmaktadır.

\section{3 Çıkarsama}

Yukarıda açıklamış olduğumuz iki gösterge Şekil 14 ve Tablo 1'de özetlenmektedir. İki görselde vurgulanan gösteren ve gösterilenleri devir teorisi (Güray, 2010) bağlamında inşa etmek mümkündür. Her iki devrin birbirleri arasındaki ayırt edici nokta ise birinde organik diğerinde mekanik dokunun varlığıdır.

Uygarlıkların tarihsel yürüyüşü üzerine yapılan felsefi çalışmalar Toynbee'nin (Toynbee, 1975, s. 91-175) döngüsel tarih yaklaşımında da olduğu gibi kadim bilgeliğin organik dünya görüşü ve onu içkin devir konseptine işaret etmektedir.

Organik dünya görüşüne göre insan ve evren Tanrı'nın işaretleriyle yüklüdür; bitki, hayvan, insan bir başka deyişle doğa da insan kadar canlı ve iletişim içerisindedir. Ayrıca uygarlıklar, bu sembolleri okuyarak kültürel eksenli bir metafiziksel döngü içerisinde doğar, gelişir, duraklar ve tükenirler. Şekil 14'te görünen döngüsel yaklaşımdaki büyü, modernitenin ortaya çıkışıyla kırılmıştır. Organik dünya görüşüne egemen olan Allah-evren ve insan birlikteliğinin yerini insanın doğa dahil her şey üzerindeki hükümranlığını meşrulaştıran Sosyal Darwinian bir ekonomik "survival" felsefesi almıştır. Toplumsal ilişkiler büyümeye endekslenmiş; tarih, ekonomi, çıkar, güdü ya da üretimtüketim ilişkilerinden ibaret sayılmıştır. Ancak kadim bilgeliğin devir kuramı bu kez makineleşmenin izdüşümünden kendini mekanik dünya görüşü olarak türetmiştir (Öke, 2015). Bunu yaparken de kadim bilgeliğin sembollerini ithal etmiştir. 
Mekanik dünya görüşünün, organik bakış açısını nasıl dönüştürüp profanlaştırarak dizayn ettiğine ilişkin süreçleri bu makalenin kapsamında irdelememiz mümkün değildir. Ancak tek bir sembol olarak geyik mithosu ele alındığında devir kuramının gerek organik gerek mekanik açılımlarını Şekil 14'te görmek mümkün olacaktır. Kadim bilgeliğin temsilinin Hacı Bektaş-i Veli görselinde, mekanik devrin de Noel Baba posterinde işlendiği görülmektedir.

ORGANIK DEVIR

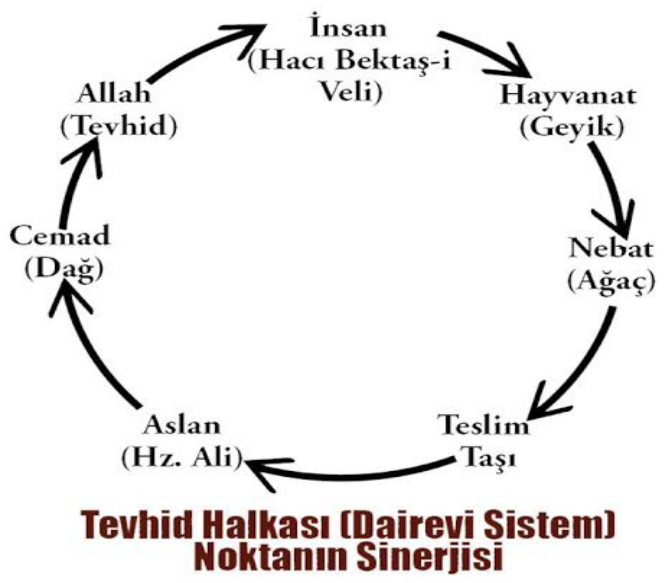

\section{MEKANIK DEVIR}

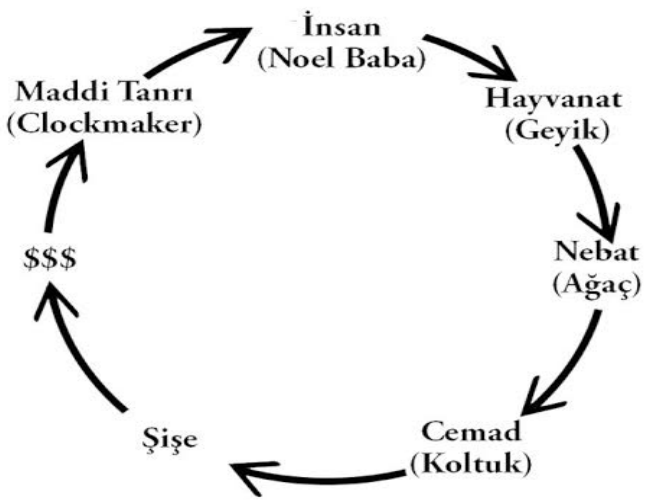

Şekil 14. Organik Devir ve Mekanik Devir

Şekil 14'te sağ tarafta görülen dairevi sistem "Mekanik Devri", sol tarafta görülen çember ise "Organik Devri" temsil etmektedir. Üzerinde ilgili uzamlar ve eyleyenler kaydedilmektedir.

Tablo 1. Görsel Okumalarının Karılaştırması

\begin{tabular}{|c|c|c|c|}
\hline \multicolumn{2}{|c|}{ GENEL ÇIKARSAMA } & \multirow{2}{*}{\begin{tabular}{|l|} 
ORGANIK DÜNYA GÖRÜŞÜ \\
HACI BEKTAŞ-İ VELI GÖRSELI
\end{tabular}} & \multirow{2}{*}{$\begin{array}{l}\text { MEKANIK DÜNYA GÖRÜŞÜ } \\
\text { NOEL BABA GÖRSELI }\end{array}$} \\
\hline \multirow{4}{*}{ 蛋 } & & & \\
\hline & INSAN & $\begin{array}{l}\text { Hacı Bektaş-i Veli } \\
\text { Allah'ın Azizi }\end{array}$ & $\begin{array}{l}\text { Noel Baba } \\
\text { Amerikan Kapitalizminin İkonu }\end{array}$ \\
\hline & KIYAFET & $\begin{array}{l}\text { Tarikat Simgeleri } \\
\text { (Destar, derviş gömleği) }\end{array}$ & $\begin{array}{l}\text { Dinamizm / Coca Cola / Kan } \\
\text { Amerikan Bayrağı'nın Kırmızısı }\end{array}$ \\
\hline & $\begin{array}{l}\text { HAYVAN } \\
\text { GEYIK }\end{array}$ & $\begin{array}{l}\text { Cemâli vasıf / Manevi araç } \\
\text { Burak }\end{array}$ & Mekanik Araç \\
\hline \multirow{3}{*}{ 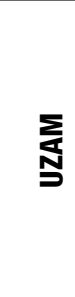 } & NEBAT & $\begin{array}{l}\text { Ağaçlar } \\
\text { Nahıl }\end{array}$ & $\begin{array}{l}\text { Suni Ağaçlar } \\
\text { (Kesilmiş) }\end{array}$ \\
\hline & ZAMAN & $\begin{array}{l}\text { Yer / Lâ zaman } \\
\text { (Hiçbir şeye dayanmıyor) }\end{array}$ & $\begin{array}{l}\text { Koltuk } \\
\text { 21.yy'da oturuyor }\end{array}$ \\
\hline & CEMAD & $\begin{array}{l}\text { Dağlar / Ulaşmak istediği sema } \\
\text { Vuslat /(.) } \\
\text { Manevi Tanrı'ya götürür }\end{array}$ & $\begin{array}{l}\text { Şişe / Para \$ } \\
\text { Maddi Tanrı'ya götürür }\end{array}$ \\
\hline
\end{tabular}

Yukarıda anlatılanların ışığında $\mathrm{Hacı}$ Bektaş-i Veli konseptinde insandan hareket edilmiş, hayvanata doğru yani geyiğe olan bir kavisle nebatata varılmış, oradan teslim taşına, teslim taşından aslana, aslandan cemâd olan dağa, oradan da semaya Allah'a varılıp tekrar insana bir dönüş yapılmıştır. Bu dairevi sistem noktanın sinerjisini göstermekte ve metafiziksel boyutta da bir tevhid halkasının dönüşümünü bize izlettirmektedir. Bu karşılaștırmalı analizin tablo olarak ifadesi ise Tablo 1'de sunulmaktadır. 
Yukarıda vurgulanmaya çalışılan saptamalarımızı bir de Barthes'in gösterge dizgesinde ifade edecek olursak karşımıza Şekil 15 çıkmaktadır.

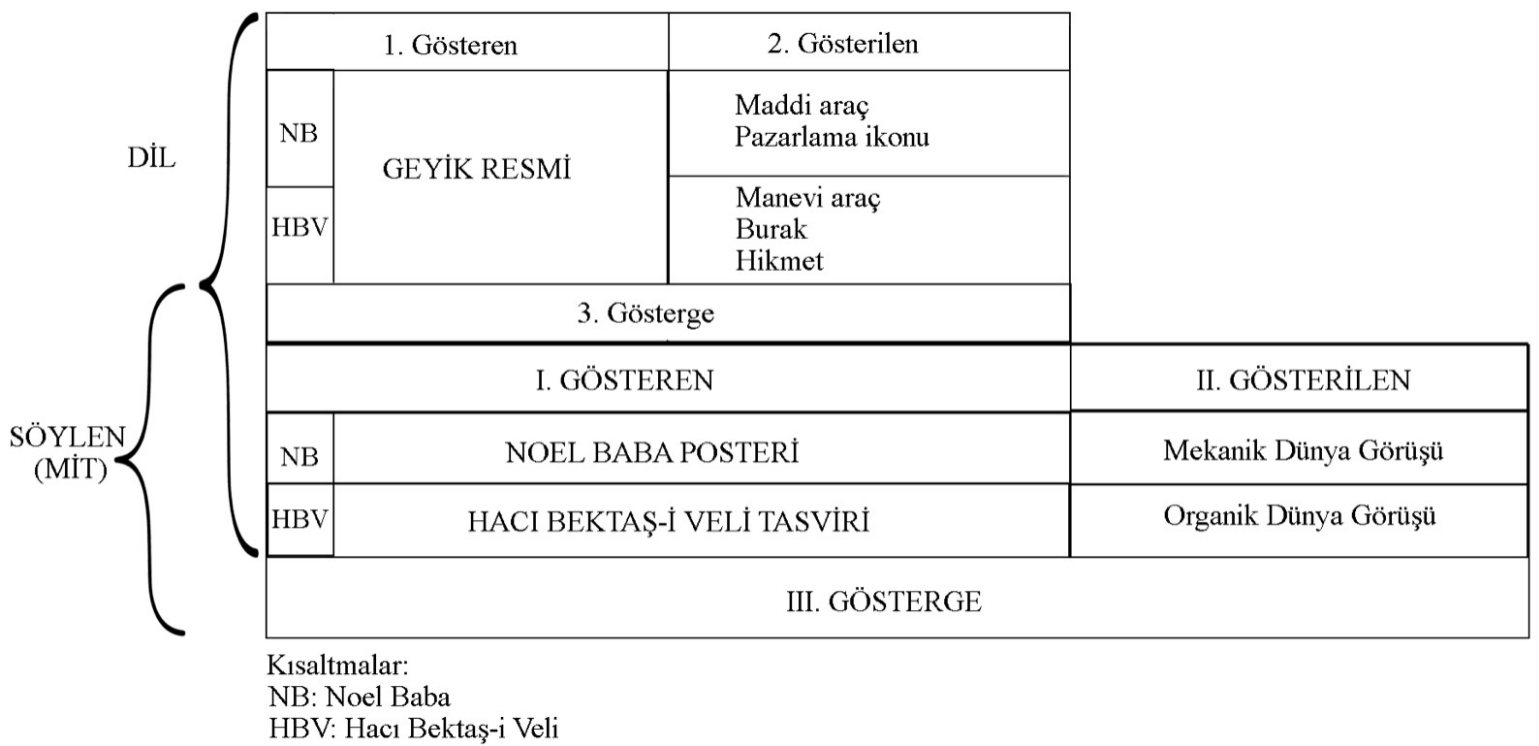

Şekil 15. Göstergelerin Karşılaştırmalı Analizi

\section{Sonuç}

Literatür araştırmalarında geyik sembolünün ruhgüder şamanı göğe çıkaran bir gök hayvanını, tasavvufta insanı sevgiliye götüren bir İnsan-ı Kamil'i, birçok Doğu ve Batı efsanesinde kahramanın güç hayvanını, sevgiliye giden yolu gösteren mukaddes bir yol göstericiyi, maddi ve manevi anlamda ilahi bir kılavuzu, avlanmasının zorluğu nedeniyle ölümsüzlük ve ulaşılmazlığı, yenilenmeyi, şekil değiștirmeyi, mutluluk, sevgi, uğur, bereket, şifa, hikmet ve huzuru temsil ettiği görülmektedir.

İncelenen mitlerin ortak noktasına bakıldığında kavramsal olarak göğe yükselme ritüelinin yani miraç temsilinin yer aldığı kahramanın Yaradan'a manevi bir binek ile ilahi yolcuğu görülmektedir. Geyik, kimi zaman ayinde şamanı göğe çıkaran gök hayvanı, kimi zaman da insanları ruhsal yolculuğuna çıkaran Burak'tır. Yol göstericilik; bazen maddi, bazen de manevi anlamdaki bir kılavuzluğu içermektedir.

İslamiyet'e götüren yolda ceylan veya geyiğin arkasından koşulur. Çünkü Hacı Bektaş-i Veli'nin görselinde ifade edilen nokta; tasavvufi bağlamda ya da Sufi literatüründe bu ceylanın aslında "Veli kültü" olmasıdır. Ceylan ile Hacı Bektaş-i Veli arasında bir özdeşleşme vardır. Önemli olan daha önce de altı çizilen bir özelliğin burada bulunmasıdır. Bu da geyiğin karnında bir kan kesesinin olması, bu kan kesesinde ise Sufi literatüründeki miski bulundurması ve bu miskin de hikmeti içermesidir. Burada hikmet ile kastedilen ilimdir, geyiğin veya ceylanın peşinden koşmakla esas ilmin peşinde koşulmaktadır. $\mathrm{Bu}$ ilim, Batı'daki anlamıyla pozitivist bilim olduğu kadar aynı zamanda irfandır, ilmi ledündür, bilgeliktir. Geyiğin arkasından koșarak aklı ve dahi ruhu temizleyerek manevi yükseliş kazanılmaktadır, irtifa kesbedilmektedir.

Noel Baba'nın geyiğindeki mekanik dünya görüşündeki konseptte de bir ilerleme vardır ama bu ilerleme ekonomi teorilerinde altı çizilen büyüme (growth) işlevselliğiyle iç içedir. İlerlemenin maddi boyutudur, ekonomik bağlamda daha zenginleşmeyi içerir. Ceylanda miskin hatırlatılması ama buradaki geyik sembolizmi içerisinde Noel Baba'nın Coca-Cola şişesini tutması bize 20. Yüzyılının likidinin misk değil de kola olduğu ve CocaCola ile insanların maddi yükselișe geçebilecekleri üzerinde durulduğu söylenebilir. Her 
iki göstergede de benzeri malzeme kullanılmakla birlikte farklı uzamlarla bunların arka planının birbiriyle ne kadar ayrıștığını fark etmek mümkündür.

Görsellerde her ne kadar ceylan kullanılmışsa da kültürel antropolojide insanlığın kolektif hafızası kültürel antropolojik simgelerin nesilden nesile aktarılması ve bu aktarım sırasında dönüşerek yeni anlamlar yüklenmeleri ile süregelmektedir. Kadim bilgeliğin ister Doğu'da ister Batı'da olsun seçmiş olduğu mitler etrafında o coğrafyanın ve dönemin ihtiyaç ve beklentileri doğrultusunda özel bir mitolojik envanter üretilir. Bu hikâyeler toplumda yukarıda işaret edildiği şekilde belli bir işlevselliğe yöneliktir. İncelememizde ceylan ve geyik motiflerinin önce nasıl mit hâline getirildiği, daha sonra ise mitolojik okumalara vesile kılındığı görülmektedir. Toplumların yaşantılarında bu mitolojiler hem evrensel benzerliklere haiz hem de kültürel özgünlükleri kendi içinde barındırmaktadır. Artemis'in geyiğinden Noel Baba'nın geyiğine dönüşüm ile şamanlardaki Tanrı'nın hayvanı geyik konsepti ile Hacı Bektaş-i Veli'nin İnsan-ı Kâmili tasvir eden geyiği simetrik okumalarda bize bu sonucu ifade etmektedir.

Burada üzerinde durulması gereken konu özellikle kültürlerarası etkileşimdir. İlginç olan bir nokta Aziz Giles'in geyikle olan münasebetidir. Bu münasebet, Abdal Musa ile Kaygusuz Abdal arasındaki ilintiyi hatırlatacak șekilde bir senkronizasyona sahiptir. Yaralı ceylanın aslında burada Aziz olduğu, Abdal Musa olayında ise Sufi olduğu görülmektedir. Benzer olay ok ve geyik gibi aynı sembollerle ilgili tasavvufi menkıbede de yaşanmış; Kaygusuz Abdal ok ile geyik donuna girmiș olan Abdal Musa'yı yaralamıștır. İki olayda da benzeri bir paralellik bulunması dikkat çekicidir ki her ikisi de sonunda şifagüder hâline gelmektedir. Geyik bağlamında kadim bilgelik mitinin dönüşerek tüketim toplumu ikonu şeklinde yeniden üretimi bize sembollerin varlığı ve işlevselliğinin zaman mekân atlasında ne kadar kalıcı olabileceğini göstermesi açısından önemlidir.

Geyik sembolünün zaman/mekan atlasında aynı kültürel havza içerisinde dahi farklı mana çağrışımları yaptırması da araştırılması gereken konulardan sayılabilir. Örneğin; Hacı Bektaş-i Veli'nin tasvirindeki geyik sembolü ile Hz. Mevlânâ'nın söylemlerindeki geyik metaforu bizleri bambaşka anlam uzamlarına götürebilir.

Bir başka öneri de burada geyik sembolüne atfedilen metafiziksel boyutun farklı bir hayvan türleri üzerinden de kurgulanabilmesidir. Yukarıda Hacı Bektaş-i Veli'nin yanında görülen aslan figürünün başlı başına ele alınıp Doğu ve Batı destanlarındaki konumu çalışılabilir. Yine bir başka örnek de, Alevî-Bektaşî deyişlerindeki turnalar olabilir. Bu çerçevede kuşlar cümlesinden hareketle Ferîdüddin Attâr'ın Mantıku't Tayr eserindeki kırk farklı kuşun kırk farklı anlama dönüştürüldüğü gözlemlenmektedir. Gerek Mantıku’t Tayr'ın gerekse yine başka bir İslam klasiği olan Tûtînâme'nin göstergebilim ışığında bilimsel çözümlenmesinin yapılması disipline katkısı açısından yararlı olabilecektir. Bu bağlamda karşılaştırmalı kültürel antropoloji içerisinde diğer simgelere de bakılabilir.

\section{Kaynakça}

Çamdereli, M. (2004). Yönetişim ve reklam iletişimi. Ankara: Nobel Yayın Dağıtım.

Çamdereli, M. (2019). İletişime giriş. İstanbul: Dem Yayınları.

Öke, M. K. (2015). Aşkın ekolojisi. İstanbul: Sufi Kitap.

Özçetin, B. (2019). Kitle iletişim kuramları. İstanbul: İletişim Yayınları.

Özkan, T. S. (2010). Bamsı Beyrek ve Bey Böyrek anlatılarında arketip imgeler. Milli Folklor Dergisi, 86. 
Öğüt, G. (2013, Aralık 14). Hürriyet. Ağustos 2020 tarihinde Noel Baba'yı Meşhur Eden Marka: https://www.hurriyet.com.tr/noel-baba-yi-meshur-edenmarka-25358076 adresinden alındı

Akcan, G. (2019). Psikoloji çerçevesinde mitoloji olgusunun incelenmesi. İ. Gümüş içinde, Mitoloji Araştırmaları (s. 51). İstanbul: Hiperlink Eğitim İletişim Yayıncılık.

Albayrak, Y. (2008). Anadolu'da Artemis kültü. Ankara: Ankara Üniversitesi.

Anastpaul. (2019). Ağustos 2020 tarihinde Saint of the Day - 1 September - St Giles: https://anastpaul.com/2017/09/01/saint-of-the-day-1-september-st-giles/ adresinden alındı

Aytaş, G. (1999). Türk kültür ve edebiyatında geyik motifi ve Haza Destân-ı Geyik. Hacl Bektaş Araştırma Dergisi, 161-170.

Barthes, R. (2018). Çağdaş söylenler. İstanbul: Metis Yayınları.

Beşkardeş, V., Uslu, Y., \& Uslu, B. (2014). Geyik ile İlgili bazı Türkçe terimler üzerine düşünceler. 2(1), 18.

Catholicsaints. (t.y.). Saint Giles: https://catholicsaints.info/saint-giles/ adresinden alındı

Cem Vakfi. (2017, Ocak 21). Temmuz 2020 tarihinde Makalât-ı Hünkâr Hacı Bektaș Veli'den: https://www.cemvakfi.org/pages/inancHizmetleriDetay/21/makalât-ihunkâr-haci-bektas-veli'den ( adresinden alındı

County Deers Talking. (2019). How did Saint Hubertus become the Patron Saint of Hunters?: https://www.countydeerstalking.co.uk/blog/how-did-saint-hubertusbecome-the-patron-saint-of-hunters.html adresinden alındı

Dalkesen, N. (2015). Orta Asya'dan Anadolu'ya Türk kültüründe geyik kültü. Milli Folklor Dergisi, 27(106).

Dervişcemaloğlu, B. (2016). Göstergebilim. Ege Edebiyat Dergisi.

Doğanay, O. (2010). Isauria heykeltraşlık sanatında Herakles'in Keryneia geyiğini yakalaması sahnesi. Pamukkale Üniversitesi Sosyal Bilimler Enstitüsü Dergisi(6), 51-60.

Eliade, M. (2006). Şamanizm. Ankara: İmge Kitabevi.

Eliade, M. (2018). Mitlerin özellikleri. İstanbul: Alfa Yayım Dağıtım.

Erginli, Z. (. (2006). Metinlerle tasavvuf terimleri sözlüğü. İstanbul: Kalem Yayınevi.

Ersoy, P. (2008). Cumhuriyet döneminde yılbaşı kutlamaları üzerine halkbilimsel bir inceleme. Ankara: Gazi Üniversitesi.

Gök, E. Ç. (2019). Türk tekstil sanatında görülen geyik figürü. Motif Akademi Halkbilimi Dergisi, 12(26).

Güngör, N. (2018). İletişim, kavram,yaklaşımlar. Ankara: Siyasal Kitabevi.

Güray, C. (2010). Semâ'dan semah'a bir sonsuz devir. Türk Kültür ve Hacı Bektaş Veli Araştırma Dergisi, 119-152.

Güzel, A. (2009). Dil-güşâ. Ankara: Türk Diyanet Vakfı.

Gavaz, Ö. S. (2016). MÖ 2. bin yıl bazı gelenek ve halk motiflerinin günümüze yansıyan örnekleri. TÜBA-AR. 
Ürkmez, E. (2015). Türk-İslâm mitolojisi bağlamında Mi'râç motifi ve Türkiye kültür tarihine yansımaları. Ankara: Hacettepe Üniversitesi.

Küçüküstel, S. (2020). Rengeyiği Türkleri - Dukhalar. İstanbul: Kolektif Kitap.

Kıran, A. E., \& Kıran, Z. (2011). Yazınsal okuma süreçleri. Ankara: Seçkin Yayıncılık.

Kemal, Y. (2016). ÜÇ Anadolu efsanesi. İstanbul: Yapı Kredi Yayınları.

Kumartaşlıoğlu, S. (2015). Geyik boynuzunun yatırlarda şifa için kullanımı. Millî Folklor Dergisi(107), 137-148.

Les Compagnons De Saint-Hubert. (t.y.). The History and the customs: http://www. lescompagnonsdesainthubert.com/the_history_and_the_customs.ws adresinden alınd

Metinlerle tasavvuf terimleri sözlüğü. (2006). İstanbul: Kalem Yayınevi.

Morristown \& Morris Township Library. (2013). Mart 2020 tarihinde Thomas Nast and Santa Claus: https://mmtlibrary.org/nj-history-genealogy/guides-for-researchpathfinders/thomas-nast-and-santa-claus/ adresinden alındı

Ocak, A. Y. (t.y.). İslam ansiklopedisi. Ağustos 2020 tarihinde Geyikli Baba: https:// islamansiklopedisi.org.tr/geyikli-baba adresinden alındı

Okuryazarim. (2018). Ağustos 2020 tarihinde Yunan Mitolojisinde Artemis: https:// okuryazarim.com/yunan-mitolojisinde-artemis/ adresinden alındı

Parla, C. (2014). Büyük Selçuklu Sultanı Melik Şah’ın Diyarbakır'da yaptırdıĞı zafer anıtı iki burca İkonografik yaklașım. Turkish Studies - International Periodical For The Languages, Literature And History Of Turkish Or Turkic, 9(10).

Rifat, M. (2009). Göstergebilimin ABC'si. Ankara: Say Yayınları.

Roux, J. P. (2005). Orta Asya'da kutsal bitkiler ve hayvanlar. İstanbul: Kabalcı Yayınevi.

Sözümüz1.blogspot. (2019, Mayıs 9). Ağustos 2020 tarihinde hoylu geyikli Baba Arzı, Düzeltmeler ve Okunuş Önerileri: http://sozumuz1.blogspot.com/2019/05/ hoylu-geyikli-baba-arz-duzeltmeler-ve.html adresinden alındı

Şahin, E. (2014). Alageyik ile avcının ölümcül dansı. Turkish Studies, 9(12), 633-646.

Tören, H. (2005). Sadreddin'in Dâsıtân-ı Geyik adlı mesnevisi. İstanbul Üniversitesi Edebiyat Fakültesi Türk Dili ve Edebiyatı Dergisi, 33(33), 239-282.

Türk Dil Kurumu Sözlükleri. (t.y.). Eylül 2020 tarihinde Genel Türkçe Sözlük: https:// sozluk.gov.tr adresinden alındı

Toynbee, A. (1975). Tarih bilinci (Cilt 1). İstanbul: Bateş Yayınları.

Un, F. H. (2011). Karşılaştırmalı Yunan ve Hint mitolojisi. Ankara.

Vedat Beşkardeș, Y. U. (2014). Geyik ile ilgili bazı Türkçe terimler üzerine düşünceler. Avrasya Terim Dergisi, 2(1), 17-24.

Weber, M. (2014). Protestan ahlakı ve kapitalizmin ruhu. Ankara: Tutku Yayınevi.

Wikipedia. (t.y.). Diana (mitoloji): https://tr.wikipedia.org/wiki/Diana_(mitoloji) adresinden alındı

Wikipedia. (t.y.). 2020 tarihinde Deer in Mythology: https://en.wikipedia.org/wiki/ Deer_in_mythology adresinden alındı 
Yayla, A. (t.y.). https://web.itu.edu.tr/ yayla/turkmit.pdf adresinden alındı Yaylagül, L. (2019). Kitle iletişim kuramları. Ankara: Dipnot Yayınları.

Youtube. (2016). Ağustos 2020 tarihinde Türk kültüründe geyik boynuzlu atlar ve şaman inancl: https://www.youtube.com/watch?v=sB360_KIqtg adresinden alındı 


\title{
Deer Symbolism as Ancient Wisdom Myth and Icon of Consumption Society
}

\author{
Oya Ayan (Ph.D. Student)
}

\section{Extended Abstract}

This article focuses on how the deer myth has become a cult from past to present. The perception of the deer myth is emphasized in the legends, epics, and rituals in which it takes place in both eastern and western civilizations. In the study, a wide scan was made and two representative images, one from the East and the other from the Western civilization, were selected.

According to organic worldview, everything in the world is a living thing. As can be seen in the old wisdom understanding, every living thing has its own sacredness. It is seen that there has been a transition from a holistic perspective to a positivist perspective with the evolution of the age and people from the past to the present. At the basis of the positivist approach is a world philosophy that is purified from the sacred and based only on science. Its reflections can be felt in many areas from people's daily lives to communication studies. In some communication studies, living beings are purified from their holiness. On the other hand, the mystical powers that permeate the genetic codes of those creatures included in myths are used for commercial purposes.

The Cervidae have been selected from the list of sacred animals in this article to make the subject more concrete. Cervidae, starting with the role of being the animal of God in many ancient civilizations, has been examined the process of transforming into the mechanical tool of Santa Claus. In this way, the article focused on the deer figure and tried to put forward how the deer mythos in question was transformed into ancient wisdom and social anthropology together with its stages. In this context, it is emphasized how a religious or even metaphysical myth is secularized, how its magic and magic are preserved, and how they have gained a unique mystical feature in the pot of liberalism. While investigating the metaphysical background of the subject, the science of myth and mythology was used. In this context, the approach of Mircea Eliade, a historian of religions and a philosopher, was taken as a basis. In the first part of the article, the concepts of myth and mythology are explained.

It is necessary to create an informational background that will facilitate the understanding of the two cultural/religious characters, one of which is a myth, the other as an icon. To do this, it would be appropriate to describe the deer symbol in its mythical referrals while examining its various aspects. In the second part of the article, there are legends, myths, epics, and books in which the religious/cultural character, which we have determined as the object of study, takes place in the East and West in the historical process under the titles The Deer Symbol in the East and the Deer Symbol in the West. Haji Bektash Veli's reading of the deer symbol section in the East will create a background for the Santa Claus reading in the West.

In the third part, a comparative visual reading is made on a picture of Haji Bektash Veli, who is absorbed in the essence of Anatolian legends as a religious myth, and a poster with Santa Claus, who has been transformed into the myth of capitalism in line with literature researches. One of the images selected for visual reading for this article shows a Santa 
Claus drinking cola and a gazelle. The relationship of Santa Claus, which has become an icon of the consumption society, with the deer has not been sufficiently investigated until today and no studies have been found on its metaphysical background. This study sets out to examine the application of the deer myth from ancient wisdom to popular culture in a comparative method.

As a method, semiotics theory, which is widely preferred in analyzing the symbolic language of visual culture and communication, was used. With the semiotics approach, the transformation of the deer symbol from the ancient wisdom myth to the consumer society icon is recorded. As a result of the comparative semiotic analysis of the two visuals, two different world views were determined. While the Santa Claus poster represents the mechanical world view, it is seen that the painting of Haji Bektash Veli represents the organic world view. This inference has been evaluated within the framework of the transfer theory. With the advent of modernity in the Santa Claus poster, the naturalness and mysticism seen in the organic period has been broken. The age of old wisdom derives itself from the projection of mechanization as a mechanical era. In doing so, he imported the symbols of ancient wisdom.

Another result is that deer have both universal similarities and cultural specificities in the lives of societies in both Eastern and Western mythology. One of the striking ones in this regard is the similarity between Saint - deer legends in Europe and Saint (Veli) - deer legends in Sufism. With the transformation from Artemis' deer to Santa Claus' deer, shamans' concept of deer, the animal of God, and Haji Bektash Veli's deer depicting Mature People express us this result in symmetrical readings. The transformation of the ancient wisdom myth in the context of the deer and its reproduction as the icon of consumer society is important in terms of showing us how permanent the existence and functionality of symbols can be in the time-space atlas.

Keywords: Communication, Deer Myth, Haji Bektash Veli, Santa Claus, Semiotics.

Bu makale intihal tespit yazilımlarıyla taranmıştır. Intihal tespit edilmemiş̧ir.

This article has been scanned by plagiarism detection softwares. No plagiarism detected.

Bu çalışmada "Yükseköğretim Kurumları Bilimsel Araştırma ve Yayın Etiği Yönergesi” kapsamında uyulması belirtilen kurallara uyulmuştur.

In this study, the rules stated in the "Higher Education Institutions Scientific Research and Publication Ethics Directive" were followed. 